\title{
INSTITUCIONALIZACIJA REFORME HRVATSKOG SUSTAVA ZNANOSTI I VISOKOG OBRAZOVANJA ${ }^{22}$
}

\author{
Ivo Družić ${ }^{23}$
}

UDC / UDK: 37.014.3:378.1:168.5(497.5)

JEL classification / JEL klasifikacija: I23, I21

DOI: https://doi.org/10.22598/pi-be/2020.14.2.141

Scientific review / Pregledni znanstveni rad

Received / Primljeno: May 20, 2019 / 20. svibnja 2019.

Accepted for publishing / Prihvaćeno za tisak: June 17, 2019 / 17. lipnja 2019.

\section{Sažetak}

Nedvojben rastući utjecaj znanosti $i$ visokog obrazovanja traži inovativnu institucionalnu koncepciju i na njoj utemeljenu strukturnu reformu sustava. Polazište je takvog pristupa zakonskog uređenja, prilagodba hrvatskoga sustava znanosti $i$ visokog obrazovanja novoj, u svjetskim razmjerima prepoznatoj, vodećoj ulozi obrazovanja $i$ znanstvenih istraživanja u ukupnom društvenom, gospodarskom, kulturnom $i$ umjetničkom kao $i$ osobnom razvoju. Ta je uloga razvidna u novim tehnološkim $i$ organizacijskim obrascima gdje ljudski potencijali postaju (infrastrukturna) pretpostavka inovativnog $i$ učinkovitog napretka. Nova uloga, pored ostalog, nosi sa sobom $i$ posebnu odgovornost znanosti $i$ visokog obrazovanja u adresiranju pratećih socijalnih izazova. Filozofski, estetski, kulturni i etički aspekti visokih tehnologija i nove stvarnosti zahtijevaju institucionalna rješenja koja potiču ubrzan razvoj $i$ sustava $i$ $k v a l i t e t e$ visokog obrazovanja te intenziviranje i podizanje međunarodne relevantnosti znanstvenih istraživanja $i$ inovacijske aktivnosti. To je temeljni preduvjet hvatanja europskog razvojnog koraka i ugradbe hrvatske nacionalne prepoznatljivosti u evoluciju europskog civilizacijskog kruga. Kako je kvaliteta istraživača i nastavnika, programa $i$ institucija, ključ reformske preobrazbe, sustav osiguranja kvalitete nužno je ugraditi kao sastavni dio odgovarajućeg zakonskog rješenja.

Ključne riječi: sustav znanosti $i$ visokog obrazovanja, reforma sustava znanosti $i$ visokog obrazovanja, institucionalni okvir, sustav osiguranja kvalitete, Republika Hrvatska.

${ }^{22}$ Istraživanje prezentirano u ovom tekstu činilo je dio znanstvene i stručne podloge u koncipiranju cjelovite reforme sustava znanosti i visokog obrazovanja i njezine institucionalizacije $\mathrm{u}$ nacrtu novog Zakona o znanstvenoj djelatnosti i visokom obrazovanju kojeg je predložilo Sveučilište u Zagrebu u ožujku 2019.

${ }^{23}$ Prof. dr. sc. Ivo Družić, redoviti profesor u trajnom zvanju, Ekonomski fakultet Sveučilišta u Zagrebu, E-mail: idruzic@efzg.hr 


\section{UVOD}

Dva su, međusobno povezana, reformska cilja predmetom raščlambe u ovom radu. Prvi je snažnije povezivanje i brže usklađivanje s potrebama hrvatskog gospodarstva i društva. Drugi je jačanje međunarodne konkurentnosti i mobilnosti. Valja istaknuti kako kvalificiranost akademske sveučilišne zajednice u prosudbi dubine potrebnih reformi ne počiva na pravu nego na odgovornosti i za svoj i za ukupan hrvatski napredak. Odgovornost prema vlastitom poslanju i hrvatskom društvu znači kako su u središtu dva subjekta koja, kao jedini stvaratelji znanstveno-obrazovne dodane vrijednosti, čine početak i kraj reformi.

Prvi je subjekt student s mentorskom praksom povezan sa svijetom rada. Polazište je prvo maksimalna usklađenosti ponude obrazovanih programa $\mathrm{s}$ identificiranim sposobnostima i sklonostima studenata, potom sa državnim strateškim razvojnim interesima $\mathrm{i}$ temeljem njih s predvidivim potrebama tržišta rada. Nema veće štete niti po individualnu produktivnost niti po nacionalnu konkurentnost, od prinude osobe da izabere struku koju niti voli niti ima za nju sklonosti. Sa stajališta nacionalnog blagostanja takva prinuda predstavlja najskuplji i nepovratan gubitak oskudnih resursa. Drugi subjekt je nastavnik/istraživač o čijoj sposobnosti gotovo isključivo ovisi stvarna realizacija propisanih ishoda učenja i stvarna kvaliteta istraživanja. Zato je prioritet reforme stvaranje poticajnog institucionalno-financijskog okvira za kvalitetnog nastavnika/istraživača prema međunarodno usporedivim kriterijima.

Učinkovita institucionalna potpora studentima i nastavnicima traži ustrojbenu konzistentnost. To, među ostalim, znači i „trodiobu ovlasti““ u sustavu između, sveučilišta, državne uprave (MZO) i državnih strateških tijela (nacionalno vijeće).

Uspješna reforma, prema našem uvjerenju, u središtu treba imati sveučilišta kao prvog $i$ najvažnijeg dionika ,trodiobe“. To pak s druge strane znači prvo, otvaranje međunarodnoj konkurenciji što uključuje i istraživačku preobrazbu sveučilišta. Drugo, to traži snažnije povezivanje i brže usklađivanje s potrebama hrvatskog gospodarstva i društva;

- jačanje međunarodne konkurentnosti i mobilnosti stimulira se izvođenjem višejezičnih obrazovnih programa na hrvatskom i svjetskim jezicima (o čemu postoji višegodišnja dobra praksa na više fakulteta). Snažniji iskorak hrvatskih sveučilišta na svjetsko tržište visokog obrazovanja ima dva temeljna cilja. Prvo, stvarnu implementaciju kriterija međunarodne izvrsnosti i rast mobilnosti. Drugo, više stranih studenata omogućuje kompenzaciju demografskog pada broja domaćih studenata a time i rast vlastitih prihoda.

- istraživačku preobrazbu sveučilišta. Priljev inozemnih studenata, povezan je i sa rangiranjem, a rangiranje u bitnome i sa kvalitetom publiciranih istraživanja. Instituti pri sveučilištima i sastavnicama, kao mogućnost a ne obveza, postaju ključ istraživačke preobrazbe $\mathrm{i}$ samostalni nositelji izvanproračunskih istraživačko-projektnih aktivnosti uključujući i doktorske studije.

- povezivanje s hrvatskim gospodarstvom i društvom potiče se na dva načina. Prvo putem sveučilišnih centara za inovacije i transfer tehnologije koji promoviraju zajedničke projekte, štite intelektualno vlasništvo i stručno 
podupiru start-up projekte u visokim tehnologijama. Drugo putem centara za cjeloživotno obrazovanje koji programima prate razvoj pojedinih struka, organiziranju izvanredne studije i mentorsku stručnu praksu studenata.

Sadržajne strukturne reforme sveučilišta imaju među ostalim dva preduvjeta. Prvi, proračunska transparentnost i drugi, autonomija uz odgovornost;

- proračunska transparentnost znači da Vlada i MZO kroz riznicu imaju kontrolu nad svim sredstvima koje država dodjeljuju sveučilištima. Sve ostalo, odnosno aktivnosti sveučilišnih znanstvenih instituta i centara za međunarodnu suradnju, transfer tehnologije, cjeloživotno obrazovanje i ostalo, kao izvori vlastitog financiranja u nadležnosti su upravljačkih tijela sveučilišta.

- autonomija uz odgovornost. Podrazumijeva savjet sveučilišta koji u novoj ulozi i proširenom sastavu osigurava javni interes. Ima zadaću strateške procjene usklađenosti sveučilišnih programa $\mathrm{s}$ društvenim potrebama $\mathrm{i}$ dugoročnim potrebama tržišta rada. Ako je ona pozitivna tada AZVO nezavisnim i transparentnim postupkom međunarodnog recenziranja utvrđuje da li je program dovoljno kvalitetan za dopusnicu. Druga bitna poluga autonomije uz odgovornost je senat sveučilišta pa prijedlog razrađuje elemente programske, financijske i upravljačke autonomije sveučilišta što uključuje i kriterije demokratskog biranja rektora i svih drugih dužnosnika.

Državna uprava (MZO) kao drugi dionik ,trodiobe“ operativno upravlja sustavom s brojnim stručnim zadaćama kao što su;

- $\quad$ analiza upisa i upisnih kvota, uspješnosti završetka studija i zapošljavanja

- vođenje evidencije nadarenih i nagrađivanih studenata

- uspostava evidencije najuspješnijih znanstvenika i najbolje ocijenjenih nastavnika

- upravni, inspekcijski i financijski nadzor

Nacionalno strateško tijelo (Nacionalno vijeće za znanost, visoko obrazovanje i tehnološki razvoj - NVZVOTR) treći je dionik, „trodiobe“. Ono po svom sastavu ojačano autoritetom Hrvatskog sabora čini kvalificirano „posredničko“ tijelo s primarnom zadaćom harmoniziranja upravno-administrativne i sveučilišno-autonomne vertikale sustava. To se među ostalim odnosi i na utvrđivanje strateških ciljeva obrazovnog procesa i znanstvenih istraživanja. Podrazumijeva razradu kriterija raspodjele proračunskih sredstava namijenjenih financiranju znanosti i visokog obrazovanja i osobito kriterija prema kojima se sklapaju ugovori o programskom financiranju između sveučilišta i MZO.

\section{CJELOVITA INSTITUCIONALNA OSNOVA REFORME}

Dosadašnja praksa institucionalizacije reformi u sustavu znanosti i visokog obrazovanja većinom je polazišta ograničavala na dva članka Ustava Republike Hrvatske. 
Prvo, na članak 68. kojim Hrvatska država jamči autonomiju sveučilišta i samostalno odlučivanje o svom ustroju i djelovanju, u skladu sa zakonom, i drugo na članak 69. kojim Hrvatska država jamči u slobodu znanstvenoga, kulturnoga i umjetničkoga stvaralaštva (st 1.), poticanje i pomaganje razvitka znanosti, kulture i umjetnosti (st. 2.), zaštitu znanstvenih, kulturnih i umjetničkih dobara kao duhovnih narodnih vrednota (st. 3.) (Ustav RH, 2010/2014). Time su postavljeni jasni institucionalni okviri unutar kojih valja ustrojiti kvalitetan sustav koji uspostavlja učinkovit odnos društvenih troškova i koristi.

Međutim, ciljevi stvarne strukturne reforma kojima se ostvaruju narečene društvene i razvojne zadaće podrazumijevaju znatno širu institucionalnu podlogu. Nju ponajprije čini ustavno uređenje Hrvatske kao socijalne države (članak 1. st. 1.). Time i visoko obrazovanje i znanstvena istraživanja dobivaju tretman javnog dobra iz čega proizlaze jasne konzekvence po ustroj, operativno upravljanje i financiranje sustava. Neokrnjeno i rastuće visoko obrazovanje i znanost kao javno dobro, bitne su pretpostavke životnosti cilja kojim hrvatska država jamči poticanje gospodarskoga napretka i socijalnoga blagostanja svojih građana (članak 49. st. 3.). Potpunu svijest o modernom stožernom značenju obrazovanja i motiviranog obrazovanog građanina za osoban i državni prosperitet ističu dva ključna ustavna opredjeljenja. Prvo, kojim Hrvatska država jamči slobodno biranje poziva i zaposlenja (članak 55. St. 2.). Već je naglašeno kako učinkovito korištenje osobnih potencijala i nacionalnih resursa u bitnome ovisi o slobodi pojedinca da bira zanimanje i posao za koji ima talent i motiv. Sloboda biranja zanimanja, podrazumijeva dakako i snošenje rizika zapošljivosti što je i sada slučaj, jer roditelji kao porezni obveznici i djeca kao učenici/studenti u potpunosti snose rizik zapošljivosti. Drugo, kojim država jamči obrazovanje dostupno svakomu, pod jednakim uvjetima, u skladu s njegovim sposobnostima (članak 66). Tim opredjeljenjem kojim Hrvatska država jasno ističe obrazovanje kao javno dobro, otvaraju se vrata potrebnom novom pristupu kojim se objektivnim kriterijima prepoznaju individualne sklonosti mladih naraštaja te prepoznaju i razvijaju talenti. Takvim pristupom koji omogućava ostvarenje punog razvojnog potencijala svakog pojedinca prema njegovim sklonostima i osobnim preferencijama optimizira se i ukupan nacionalan razvitak.

Realno bi bilo za očekivati kako će ovako jasna temeljna institucionalna polazišta biti transparentno razrađena u izvedbenim (zakonskim) rješenjima. No zbiva se upravo obrnuto. Sustav se regulira brojnim propisima; zakonima, uredbama, pravilnicima, poslovnicima, naputcima, uputama i odlukama. Primjera radi samo se zakonodavni okvir temelji na:

- Zakonu o znanstvenoj djelatnosti i visokom obrazovanju-pročišćeni tekst ( $N N$ 123/03., 105/04., 174/04., 2/07. - Odluka Ustavnoga suda Republike Hrvatske, 46/07., 45/09., 63/11., 94/13., 139/13., 101/14. - Odluka Ustavnoga suda Republike Hrvatske, 60/15. - Odluka Ustavnoga suda Republike Hrvatske, i 131/17. - Uredba Vlade Republike Hrvatske)

- Zakonu o akademskim i stručnim nazivima i akademskom stupnju (NN 107/07, $118 / 12)$

- Zakonu o hrvatskom kvalifikacijskom okviru (NN 22/13, NN 41/16 - Odluka Ustavnoga suda, 64/18) 
- Zakon o osiguranju kvalitete u znanosti i visokom obrazovanju ( $N N 45 / 09)$

- Zakon o Hrvatskoj zakladi za znanost (NN 117/01, 92/10, 78/12).

Veliki broj, često međusobno neusklađenih, zakonskih i podzakonskih akata i drugih propisa, umjesto učinkovite potpore, pretvara sustav u birokratski labirint, a snalaženje u njemu zahtjeva posebnu vještinu. Stoga ne čudi i dodatna blokada sustava kao rezultat relativno velikog broja pravnih sporova čime još jedan zakon (Zakon o općem upravnom postupku $(N N 47 / 09))$ praktički postaje dijelom sustava znanosti i visokog obrazovanja.

Imajući na umu neučinkovit, a često i kontradiktoran karakter narečenih propisa, valja konstatirati kako ti zakoni oblikuju temeljni institucionalni okvir za razvoj i provedbu znanstvene djelatnosti i visokoga obrazovanja u Republici Hrvatskoj te razvoj sustava potrebnoga za njezino ostvarenje.

Sustav znanstvenih organizacija Republike Hrvatske čini 8 javnih, 2 privatna sveučilišta, 25 javnih znanstvenih instituta te 66 javnih i privatnih ustanova i trgovačkih društava koja su akreditirana za znanstvenu djelatnost.

Najviše državno strateško stručno tijelo koje se brine za razvitak, kvalitetu i utvrđivanje kriterija financiranja cjelokupne znanstvene djelatnosti i sustava znanosti, visokoga obrazovanja, tehnološkoga razvoja i inovacijskoga sustava u Republici Hrvatskoj jest Nacionalno vijeće za znanost, visoko obrazovanje i tehnološki razvoj (u daljnjem tekstu: Nacionalno vijeće), kojeg imenuje Hrvatski sabor.

Središnje tijelo državne uprave nadležno i odgovorno za funkcioniranje, razvoj i financiranje znanstvene djelatnosti i visokoga obrazovanja je Ministarstvo znanosti i obrazovanja (u daljnjem tekstu: MZO), koje predlaže i provodi stručne mjere za unapređenje sustava te nadzire utrošak sredstava državnoga proračuna za financiranje visokoobrazovne i znanstvene djelatnosti.

Hrvatska zaklada za znanost neovisna je institucija koja osigurava financijsku potporu za provedbu znanstvenih projekata prema kriterijima znanstvene izvrsnosti u skladu sa strateškim ciljevima koje utvrđuje Nacionalno vijeće.

Agencija za znanost i visoko obrazovanje neovisna je javna ustanova koja brine o osiguravanju i unapređivanju kvalitete u znanosti i visokom obrazovanju te provodi postupke akreditacije i vrednovanja visokih učilišta i znanstvenih organizacija, u skladu s kriterijima kvalitete koje donosi Nacionalno vijeće.

\section{INOVIRANJE INSTITUCIONALNOG OKVIRA}

Opći razlog za donošenje novog cjelovitog zakonskog rješenja jest potreba prispodobe hrvatskoga sustava novoj, u svjetskim razmjerima prepoznatoj, vodećoj ulozi obrazovanja i znanstvenih istraživanja u ukupnom društvenom, gospodarskom, kulturnom i umjetničkom kao i osobnom razvoju. Pod tim se u velikoj mjeri podrazumijeva institucionalizaciju odgovarajućih ciljeva i mjera izvornoga dokumenta Strategije obrazovanja, znanosti i tehnološkog razvoja (Strategija, 2014). Ubrzani razvoj novih tehnologija i inovativnih procesa rezultira promjenom cjelokupne tehnološke 
paradigme u kojoj je ljudski rad, pored prirodnih resursa i proizvodnoga kapitala, bio tek jedan od triju proizvodnih faktora. U novim tehnološkim i organizacijskim obrascima, ljudski potencijali postaju (infrastrukturna) pretpostavka inovativnoga učinkovitoga korištenja ostalih dvaju faktora; prirodnih resursa i proizvodnoga kapitala.

Pored ovoga općega, Hrvatska ima i specifičan razlog. Duboka strukturna reforma sustava potrebna je kako bi zemlja izišla iz „zamke srednjega dohotka“. Naime, Hrvatska je još 1980. dostigla razinu industrijski srednje razvijene zemlje i suočila se s problemom koji je identificirao ekspertni tim Svjetske banke predvođen nobelovcem M. Spencom proučavajući, u osvit krize 2008., svjetski razvoj nakon II. svjetskoga rata. „Izvještaj“ navodi: „Zemlje srednjega dohotka imaju problem održanja razvojnoga zamaha kako se približavaju razvijenima. Kako nadnice rastu gubi se konkurentnost $\mathrm{u}$ radno intenzivnim industrijama. Tada rast mora generirati znanje, obrazovanje, inovativnost kako bi poduprli rastuće uslužne sektore (World Bank, 2008).“

Koliko je to složena zadaća govore podaci da je samo šest ekonomija (Hong Kong, Japan, Južna Koreja, Malta, Singapur, Tajvan) u 60 godina nakon II. svjetskoga rata uspjelo zatvoriti razvojni jaz i priključiti se visokorazvijenim zemljama. Ostale zemlje, a među njima i Hrvatska, odabrale su neku od varijanti stabilizacijske strategije s posljedicom širenja razvojnoga jaza odnosno razvojnoga zaostajanja.

Opći i poseban slijevaju se u stožeran razlog - potrebu takva uređenja sustava znanosti i visokog obrazovanja koje će

- poticati individualnu, međunarodno usporedivu, kvalitetu i znanstvenih istraživanja i poučavanja. Poticanje rasta kvalitete kao ključan razlog donošenja novoga zakona ima svoju pretpostavku u takvim institucionalnim rješenjima koja osiguravaju potpunu slobodu istraživača u predmetu, sadržaju i metodama istraživanja, analize i debate. Rješenjima koja potiču „nesmiljeno“ inovativno kritičko promišljanje koja svako prekrajanje znanstvene istine destimuliraju kao „izdaju intelektualca“ (Benda, 1997). Primarna svrha osobito temeljnih istraživanja $\mathrm{u}$ prirodnim $\mathrm{i}$ društvenim te humanističkim znanostima nije postizanje nekoga unaprijed (izvana) zadanoga cilja koji onda postaje i mjerilo uspjeha. Upravo obrnuto, svrha je samo propitivanje, poticanje duhovne, intelektualne, istraživačke radoznalosti koja pomičući granice spoznaje nadmašuje našu trenutnu sposobnost ne samo objašnjenja aktualnih fenomena nego i sadašnju sposobnost formulacije istraživačkih problema. U temeljnim, ali i u primijenjenim istraživanjima praktičan, primjenjiv rezultat ne samo da nije zajamčen ishod, nego je često „neočekivan“ i „nenamjeravan“ rezultat drukčijih početnih ideja i projekata drukčije namjene i cilja. Donekle se slično zbiva i u umjetničkoj produkciji. Pokatkad je nužno ,proizvesti“ desetke verzija rukopisa, scenarija ili probnih glazbenih snimaka da bi se u konačnici dogodila „uspješnica“ koja će višestruko premašiti „troškove“ ostalih „neuspjeha“ (Družić, 2014),

- poticati i institucionalno urediti rastuću društvenu odgovornost pojedinca i sustava za ukupan razvitak hrvatske države. Pod tim se podrazumijeva odgovornost za otvaranje društvene i gospodarske prakse stubokim promjenama koncepcije čovjeka i ljudskoga života na individualnoj razini. Dešifriranje 
ljudskoga genoma i genetskoga koda biljnoga i životinjskoga svijeta otvorilo je vrata sasvim novim oblicima tretiranja bolesti personaliziranom medicinom, a genetski inženjering takve kombinacije između vrsta koje mijenjaju sam pojam životnih potreba i koncept njihovog zadovoljavanja. U tijeku je još kudikamo složeniji proces mapiranja ljudskoga mozga praćen ubrzanjem otkrića u sintetskoj biologiji. To znači da nam slijedi novi svijet $\mathrm{s}$ nepoznatim mogućnostima produljenja ,prirodnoga“ života ali i još nespoznati pravci razvoja „umjetnog“ života odnosno „umjetne“ inteligencije. Na nacionalnoj razini ona podrazumijeva odgovornost za znanstveno-stručnu podlogu ukupnoga društvenoga razvoja koja proizlazi iz razvidnoga preokreta razvojnih čimbenika definiranih kao IV. industrijska revolucija. Njezino su glavno obilježje virtualno- fizički sustavi (eng. cyber-physical systems - CPS) koji ujedinjuju informacijsku (IT) i operacijsko-proizvodnu (OT) tehnologiju, tvoreći "Internet stvari" (IOT). Vrtoglava brzina IV. industrijske revolucije širi njezin početni koncept iz prerađivačke industrije u promet, logistiku (opskrbu), pametne zgrade i pametne gradove, energetiku, pametnu zdravstvenu skrb i brojne druge aplikacije koje i „Internet stvari“ nadograđuju u „Internet stvari, podataka i usluga“. Izravna posljedica toga „razmicanja“ granica između virtualnoga (cyber) i realnoga (stvarnoga, fizičkoga) svijeta jest postupan nestanak brojnih današnjih struka i zanimanja povezanih $\mathrm{s}$ industrijskim i uslužnim fizičkim radom te nastanak novih, temeljenih na sposobnostima inovativnoga razmišljanja i visokom obrazovanju. Procjene su u rasponu od onih prema kojima je 47\% sadašnjih poslova u SAD-u pod rizikom nestanka (Frey, Osborne, 2013), do radikalnih prema kojima će 65\% djece koja danas započinju osnovno obrazovanje na kraju raditi u zanimanjima koja danas još ne postoje (World Economic Forum, 2016). Ovdje je razlog za novo zakonsko rješenje podcrtan nužnošću da institucionalna rješenja istaknu kako „prosvjetiteljska“ misija transfera $\mathrm{i}$ inovativnoga adaptiranja tuđih uspješnih razvojnih iskustava, strategija i novih tehnologija, čini tek dio društvene uloge hrvatskoga sustava visokoga obrazovanja i znanstvenih istraživanja. Njegova je odgovornost daleko veća. On mora institucionalnim rješenjima poticati inovacije i vlastiti razvoj tehnologija kompatibilnih nacionalnim prirodnim, proizvodnim i ljudskim potencijalima,

- poticati kolektivnu (samo)odgovornost i aktivnost pripadnika akademske zajednice na izradi takva institucionalnoga (zakonskoga) ustroja sustava, koji će sankcionirati njihovu rastuću individualnu i društvenu odgovornost. Krucijalan razlog potrebe novoga zakonskoga rješenja jest institucionalno pozicionirati sveučilišnu autonomiju kao (samo)odgovornost za slobodu i kvalitetu visokoobrazovnoga procesa $\mathrm{i}$ istraživanja. Polazeći od činjenice da nitko nije bolje kvalificiran, u znanstveno-stručnom pogledu, ocijeniti kvalitetu nastavnika, programa i institucija od akademske zajednice, nužno je od nje tražiti dragovoljno podvrgavanje strogim moralnim načelima i razrađenom etičkom kodeksu. Posebna se odgovornost odnosi na adresiranje pratećih socijalnih izazova. Filozofski, estetski, kulturni i etički aspekti nove stvarnosti zahtijevaju 
institucionalna rješenja koja potiču ubrzan razvoj i sustava i kvalitete visokoga obrazovanja te intenziviranje i podizanje relevantnosti znanstvenih istraživanja $\mathrm{i}$ inovacijske aktivnosti. To je temeljni preduvjet hvatanja europskog razvojnog koraka i ugradbe nacionalne prepoznatljivosti u evoluciju europskoga civilizacijskoga kruga.

Naposljetku, razlog za novo zakonsko rješenje jest neposredna potreba takva odnosa između ocjene stanja, ciljeva i rješenja za njihovo ostvarenje, kojima se operativno uspostavlja logičan i razložit poredak reformskih prioriteta. To znači da se stvarne, sadržajne reforme moraju plesti isključivo oko dvaju subjekata koja, kao jedini stvaratelji znanstveno-obrazovne dodane vrijednosti, čine početak i kraj reformi. Sve ostalo su institucionalni i ustrojbeni podupiratelji i poticatelji.

Prvi stožerni subjekt je student, organski povezan sa svijetom rada, ohrabrivan u buđenju intelektualne radoznalosti, te u punoj kritičkoj i kreativnoj slobodi. Interakcija studiranja/istraživanja i svijeta rada čini studiranje relevantnim, a društvenu praksu sposobnu odgovoriti socijalnim, tehnologijskim i drugim izazovima. Polazište je, prije svega, maksimalna usklađenost ponude obrazovnih programa $\mathrm{s}$ identificiranim sposobnostima i sklonostima studenata, potom sa strateškim razvojnim interesima društva i države, a tek nakon toga s trenutačnim potrebama tržišta rada. Nema veće štete niti po individualnu produktivnost niti po društvenu konkurentnost, od prinude osobe da radi posao koji niti voli niti ima za nj sklonosti. Sa stajališta nacionalnoga blagostanja, takva prinuda predstavlja razoran i najskuplji gubitak nacionalnih resursa.

Drugi stožerni subjekt je nastavnik/istraživač, sposoban prenositi znanje i osobito poučavati kako učiti i istraživati. On je ključan, stvaran provoditelj reforme. Istinska realizacija propisanih ishoda učenja i stvarna kvaliteta istraživanja bit će onoliko životni koliko su sposobni i motivirani nastavnici/istraživači. Zato je nezaobilazan razlog reforme stvaranje poticajnoga institucionalno-financijskoga okvira za kvalitetnoga nastavnika/istraživača prema međunarodno usporedivim kriterijima.

\section{OCJENA STANJA KAO POLAZIŠTE INSTITUCIONALNIH REFORMI}

Razvoj hrvatskoga sustava znanosti i visokoga obrazovanja usko je povezan i ima bitan dugoročan utjecaj na smjer, dinamiku i ishode ukupnoga razvoja hrvatskoga društva. U uvjetima pune međunarodne otvorenosti i članstva u Europskoj uniji koje podrazumijeva zajedničke politike (monetarnu, fiskalnu, carinsku, poljoprivrednu, migracijsku, trgovinsku i druge), nacionalni sustav znanosti i visokoga obrazovanja $u$ okviru Europskoga istraživačkog prostora (ERA) i Europskoga prostora visokoga obrazovanja (EHEA), ima posebnu ulogu i odgovornost. One se odnose na potrebu neprekidnoga širenja kanala međunarodne komunikacije i suradnje u svim znanostima. To je pak preduvjet stalnog kritičkoga propitivanja tuđih i vlastitih spoznaja i praksi kako bi se prepoznali, inovirali i redizajnirali procesi što potiču kreiranje razvojnih niša i oblikovanje modernoga nacionalnoga identiteta. 


\subsection{Znanost}

Komparativnom analizom podataka iz statističkih publikacija EU bjelodano je zaostajanje RH u 2000-ima, osobito nakon krize 2008. godine. Hrvatska se nalazi uglavnom između 25. i 27. mjesta od donedavnih 28 članica EU prema svim bitnim elementima znanstvene politike: znanstvenoj produktivnosti mjerenoj međunarodnom vidljivošću i citiranošću, broju istraživača u ekvivalentu punog radnog vremena (FTE), inovativnosti i broju patenata, broju i razvijenosti istraživačkih jedinica u gospodarskim subjektima, izdvajanjima poslovnog sektora za istraživanje i razvoj, nacionalnim javnim/proračunskim izdvajanjima.

Narečeno rezultira osobito zabrinjavajućom činjenicom prema kojoj je hrvatska znanost „zarobljena“ u tzv. niskoj ravnoteži odnosno ravnoteži pri relativno visokom stupnju „nezaposlenosti“ znanstvenih resursa. Prema međunarodnim analizama (časopis Nature 2014) Hrvatska, na općenito niskoj razini ukupnih ulaganja, relativno efikasno ulaže u znanost. Dakle relativno mali broj radova objavljen s još manje uloženih financijskih sredstava daje rezultat nešto iznad prosjeka.

Valja istaknuti kako su vrlo rijetke zemlje koje politiku rezanja javnih izdataka odnosno „tvrdih proračunskih ograničenja“ primjenjuju na obrazovanje i znanost, jer su svjesne da je to rezanje (razvojnih) „grana“ na kojima (nacionalna) ekonomija „sjedi“.

\subsubsection{Hrvatski i EU trendovi znanstvenih istraživanja}

Europska je unija identificirala „velikih 5“-Amazon, Apple, Facebook, Google, Microsoft, - kao „kralježnicu“ oporavka i nove razvojno-konkurentske dinamike SAD-a nakon krize 2008. Europski strateški „odgovor“ u području znanosti jest modeliranje platformi koje će ubrzati transformaciju evidentno kvalitetnoga znanstvenoistraživačkoga doprinosa u inovacijsku primjenu i nove tehnologije. Motor novoga razvoja su inter/multi/transdisciplinarna istraživanja kojima se integriraju STEM i DH (društvenohumanističko) područja u njegovu cjelovitu tehnološko inovacijsku podlogu i preduvjet. Vjerodostojnosti odlučnosti EU da promijeni stanje i podigne konkurentnost svojih znanstvenih istraživanja i inovacija, pridaje opredjeljenje da se izdvajanje za istraživanje i razvoj (I\&R) od prosječnih oko 2\% u 2014. (Tablica 1) u 2020-tim poveća na 3\% BDP. Pored povećanja izdvajanja poslovnoga sektora to podrazumijeva da se nakon 2020 . udvostruči proračun EU za razvoj i istraživanje (European Commission, 2017a).

Hrvatska se sa $0,79 \%$ izdataka za I\&R u 2014. nalazi na 25. mjestu između 28 članica EU. Hrvatska se sa 1,03\% izdataka za I\&R u 2004. nalazila na 16. mjestu između 28 članica EU. Hrvatska je jedina članica EU koja je u desetljeću 2004-2014 smanjila ukupan iznos izdvajanja za I\&R od 345 na 340 milijuna $€$ (Tablica 1.)

Tablica 1. Izdaci za istraživanje i razvoj (\% udjel u BDP-u i u apsolutom iznosu, milijuni eura) 2004. i 2014.

\begin{tabular}{|l|l|l|l|l|l|l|l|}
\hline & & $\%$ & mil. $€$ & & & $\%$ & mil. $€$ \\
\hline Zemlja & Rang 2004. & $\mathbf{2 0 0 4}$ & $\mathbf{2 0 0 4}$ & Zemlja & Rang 2014. & $\mathbf{2 0 1 4}$ & $\mathbf{2 0 1 4}$ \\
\hline Švedska & 1 & 3,39 & 10426 & Finska & 1 & 3,17 & 6512 \\
\hline Finska & 2 & 3,31 & 5253 & Švedska & 2 & 3,16 & 13612 \\
\hline Danska & 3 & 2,42 & 4897 & Danska & 3 & 3,08 & 7952 \\
\hline
\end{tabular}




\begin{tabular}{|l|l|l|l|l|l|l|l|}
\hline Njemačka & 4 & 2,42 & 54967 & Austrija & 4 & 2,99 & 9833 \\
\hline Austrija & 5 & 2,17 & 5250 & Njemačka & 5 & 2,84 & 82866 \\
\hline Francuska & 6 & 2,09 & 35693 & Belgija & 6 & 2,46 & 9875 \\
\hline Belgija & 7 & 1,81 & 5404 & Slovenija & 7 & 2,39 & 890 \\
\hline Nizozemska & 8 & 1,81 & 9469 & Francuska & 8 & 2,26 & 48108 \\
\hline Luksemburg & 9 & 1,62 & 448 & Češka & 9 & 2 & 3091 \\
\hline UK & 10 & 1,61 & 29834 & Nizozemska & 10 & 1,97 & 13075 \\
\hline Slovenija & 11 & 1,37 & 379 & UK & 11 & 1,72 & 38323 \\
\hline Irska & 12 & 1,18 & 1840 & Irska & 12 & 1,55 & 2871 \\
\hline Češka & 13 & 1,15 & 1100 & Estonija & 13 & 1,46 & 286 \\
\hline Italija & 14 & 1,05 & 15253 & Mađarska & 14 & 1,38 & 1429 \\
\hline Španjolska & 15 & 1,04 & 8946 & Italija & 15 & 1,29 & 20770 \\
\hline Hrvatska & $\mathbf{1 6}$ & $\mathbf{1 , 0 3}$ & $\mathbf{3 4 5}$ & Portugal & 16 & 1,29 & 2229 \\
\hline Mađarska & 17 & 0,87 & 721 & Luksemburg & 17 & 1,24 & 614 \\
\hline Estonija & 18 & 0,85 & 83 & Španjolska & 18 & 1,2 & 12725 \\
\hline Litva & 19 & 0,75 & 137 & Litva & 19 & 1,02 & 370 \\
\hline Portugal & 20 & 0,73 & 1110 & Poljska & 20 & 0,94 & 3864 \\
\hline Poljska & 21 & 0,56 & 1139 & Slovačka & 21 & 0,89 & 670 \\
\hline Grčka & 22 & 0,53 & 1021 & Malta & 22 & 0,85 & 67 \\
\hline Slovačka & 23 & 0,5 & 174 & Grčka & 23 & 0,83 & 1482 \\
\hline Malta & 24 & 0,49 & 24 & Bugarska & 24 & 0,8 & 335 \\
\hline Bugarska & 25 & 0,48 & 99 & Hrvatska & 25 & 0,79 & 340 \\
\hline Latvija & 26 & 0,4 & 47 & Latvija & 26 & 0,68 & 163 \\
\hline Rumunjska & 27 & 0,38 & 235 & Cipar & 27 & 0,47 & 83 \\
\hline Cipar & 28 & 0,34 & 47 & Rumunjska & 28 & 0,38 & 575 \\
\hline
\end{tabular}

Izvor: Eurostat „News Release 209/2015

\subsubsection{Kompatibilnost znanstvenoistraživačkih politika Hrvatske i Europske komisije (EK)}

Ovakva je ocjena razvidno polazište EU u motrenju hrvatskoga sustava znanosti i visokoga obrazovanja. EU za ostvarenje nekolicine ključnih strateških ciljeva „bilancira“ konkretna potrebna financijska sredstva, čineći tako svoju strategiju održivom i izvedivom. Držeći se istih načela, Europska komisija (EK) redovito (godišnje) ocjenjuje pripravljenost svake članice, pa tako i Hrvatske, da svojom politikama ostvaruje nacionalne ciljeve i doprinese rastu kvalitete i konkurentnosti znanstvenih istraživanja $\mathrm{i}$ inovativnosti Europske unije.

Europska komisija konstatira kako je zaostajanje hrvatskoga sustava I\&R za ostalim članicama EU uvelike rezultat oskudnih javnih ulaganja, a potom i; fragmentiranosti hrvatskih institucija visokoga obrazovanja, nedostatka poticaja za karijere istraživača, zanemarivanja relevantnosti internacionalizacije hrvatske znanstvene i inovacijske arene (European Commission, 2018).

Trendovi izdataka potvrđuju redoslijed uzroka hrvatskoga zaostajanja, koji na prvo mjesto stavlja javno financiranje. Hrvatski izdaci (2005) za I\&R od 72,5€ po stanovniku bili su za 5,6 puta $(560 \%)$ niži od EU prosjeka od $408,6 €$. Deset godina poslije (2014.), hrvatskih $80 €$ bilo je 7 puta niže (700\%) od prosjeka EU od 558,4€ (Tablica 2.) 
Tablica 2. Bruto domaći izdaci za I\&R po stanovniku od 2005. do 2014. (u eurima $€$ )

\begin{tabular}{|l|l|l|l|l|l|l|l|l|l|l|}
\hline Zemlja & 2005. & 2006. & 2007. & 2008. & 2009. & 2010. & 2011. & 2012. & 2013. & 2014. \\
\hline EU & 409 & 436,1 & 460,8 & 479,7 & 472,9 & 490,9 & 516,7 & 535,6 & 542,4 & 562,4 \\
\hline Hrvatska & 72,5 & 69 & 80,7 & 98,7 & 88,3 & 77,9 & 78,4 & 77,2 & 83,2 & 80 \\
\hline
\end{tabular}

Izvor: Eurostat (2019a)

Dosad izloženi raskoraci Hrvatske u odnosu na znanstveno obrazovne politike gotovo svih ostalih članica EU rezultirali su decimiranjem ljudskih istraživačkih potencijala kao pretpostavkom i odlučujućim čimbenikom kvalitete i konkurentnosti. U 2016. godini Hrvatska je prema broju od 1,8 istraživača na 1000 stanovnika također na dnu EU ljestvice, jedino su Cipar i Rumunjska iza naše zemlje (Grafikon 1). 
Grafikon 1. Broj istraživača na 1000 stanovnika

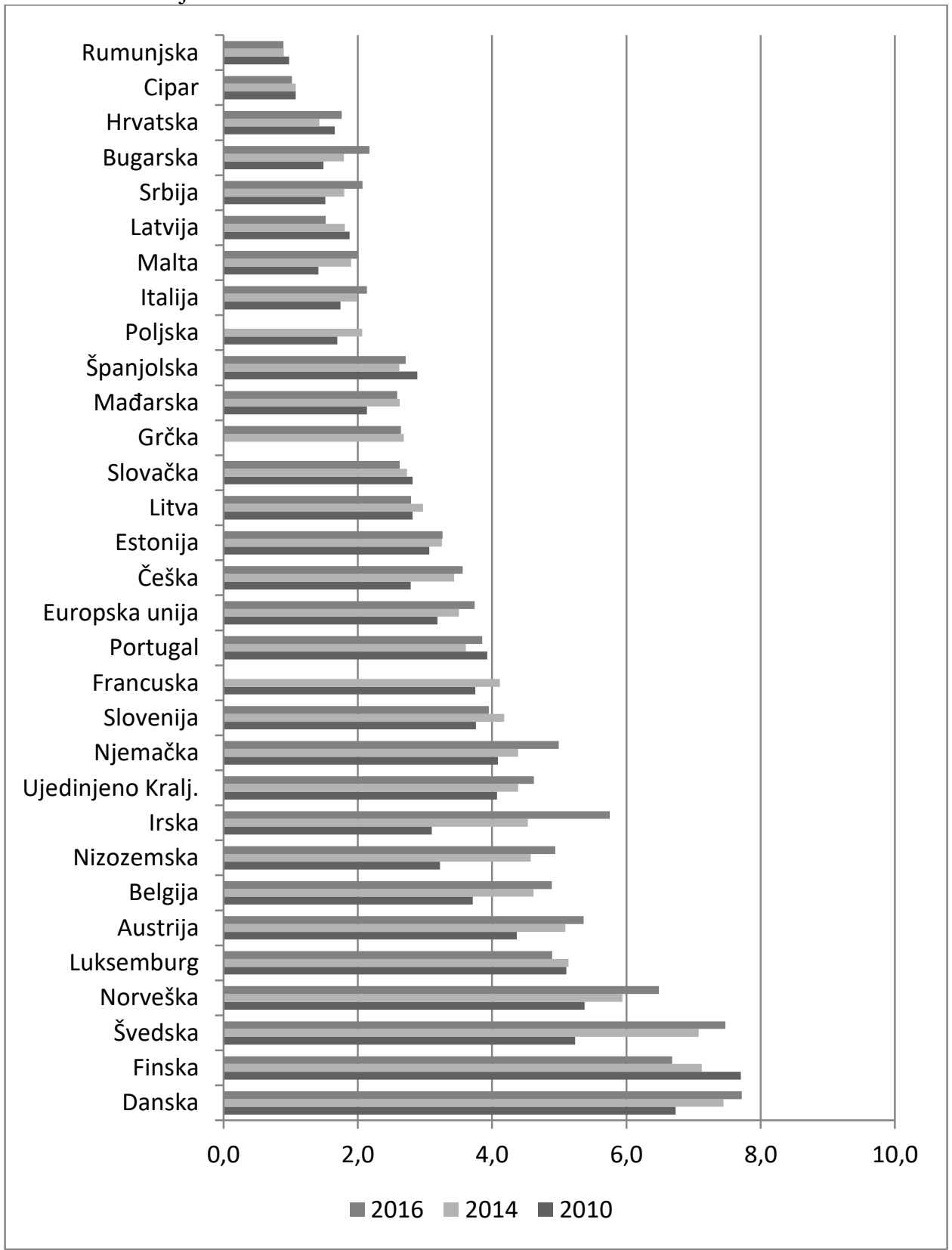

Izvor: Eurostat (2019b) 
Kombinacija dugoročno niskih ulaganja i posljedično maloga broja istraživača dovela je Hrvatsku na posljednje mjesto prema JRC indikatoru znanstvene izvrsnosti, koji je sintetski pokazatelj broja izvrsnih članaka, međunarodnih patenata i ERC grantova po stanovniku (Grafikon 2.).

Grafikon 2. JRC kompozitni indikator znanstvene izvrsnosti

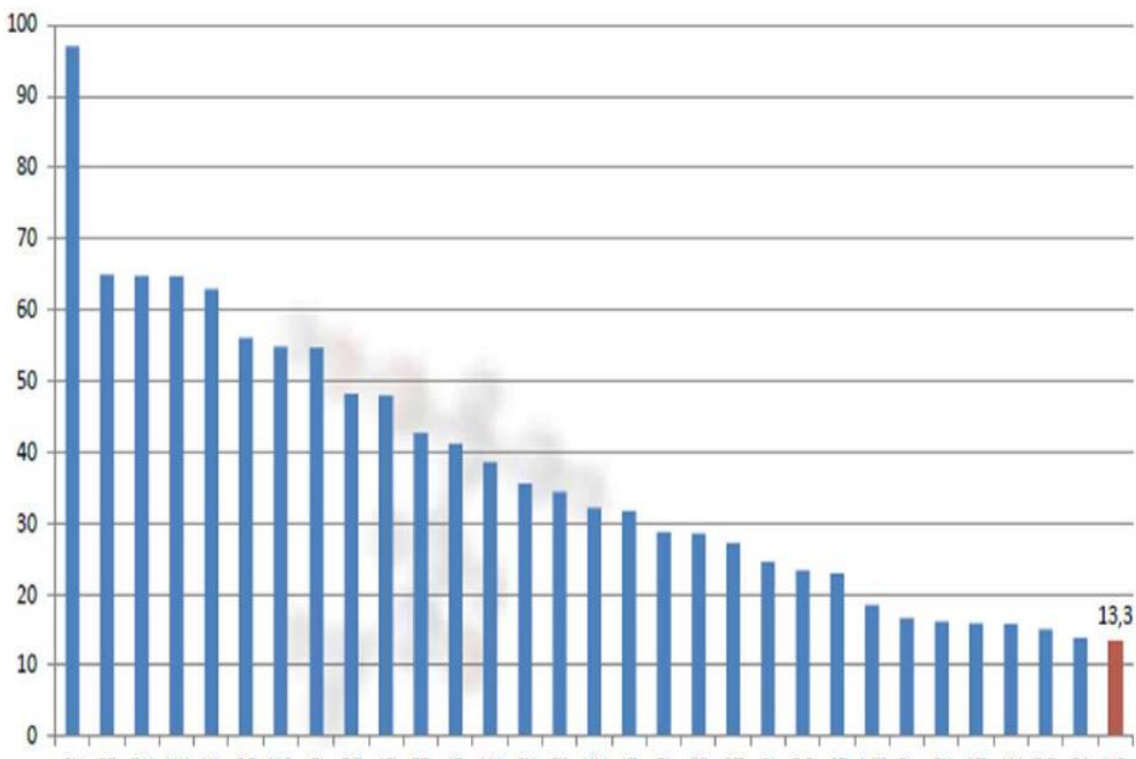

Izvor: Europska komisija (2015)

Veliko značenje pojedinih elemenata kompozitnoga indikatora (vrhunska znanost i ERC projekti/grantovi inovacije i projekti/grantovi (Obzor 2020) traži njihovu pojedinačnu analizu.

Vrhunska znanost. Predstavlja postotak objavljenih vrhunskih znanstvenih radova u odnosu na sve objavljene znanstvene radove. Prema tom indikatoru Hrvatska je (opet) na 25. mjestu s oko $4 \%$ od ukupnog broja znanstvenih publikacija objavljenih u $10 \%$ visoko citiranih znanstvenih publikacija (Grafikon 3). Kako vidimo, vrhunska znanstvena produkcija od $4 \%$ gotovo je konstantna tijekom petnaestak godina. Kada pak tako nepovoljan pokazatelj usporedimo s podatkom o padu udjela izdataka za I\&R u BDP-u za 23\% (od 1,03 na 0,79) i padu apsolutnoga iznosa od 345 na 340 milijuna eura, dobijemo potpuniju sliku. Hrvatska nije tijekom tih 15 godina povećala vrhunsku znanstvenu produkciju (broj publikacija). To je svakako veliki neuspjeh. Istodobno Hrvatska je $\mathrm{u}$ istom razdoblju povećala znanstvenu produktivnost (isti broj publikacija $\mathrm{s}$ manje sredstava). Isti rezultat s gotovo $1 / 4$ nižim udjelom izdataka za I\&R nije zanemariv uspjeh. No on upućuje na dostignutu graničnu efikasnost sustava odnosno iscrpljivanje unutarnjih rezervi i žurno potrebnih poticajnih financijskih i institucionalnih reformi. 
Grafikon 3. Vrhunskih 10\% visokocitiranih publikacija 2000., 2007. i 2014.

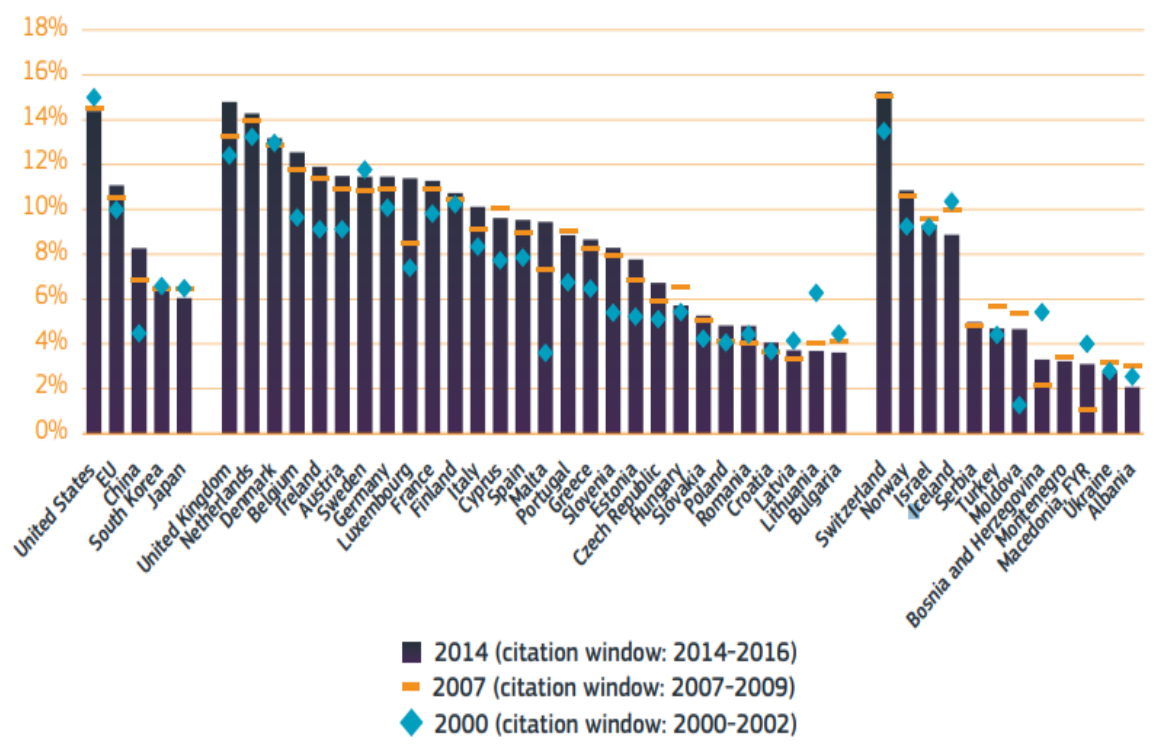

Izvor: European Commission (2018b), Figure 1.4-A.4, str. 159

Situacija stagnirajuće vrhunske znanstvene „proizvodnje“ uz rastuću „produktivnost“, snažno se negativno reflektira na međunarodnu konkurentnost. Nedovoljna visokocitirana znanstvena produkcija transformira se u činjenicu kako je Hrvatska nositelj tek dvaju vrhunskih ERC grantova/projekata. Usporedbe radi, Slovenija i Litva imaju po 1, Finska 56, a Belgija 100 (Grafikon 4.). 
Grafikon 4. Broj ERC projekata po zemljama 2017.

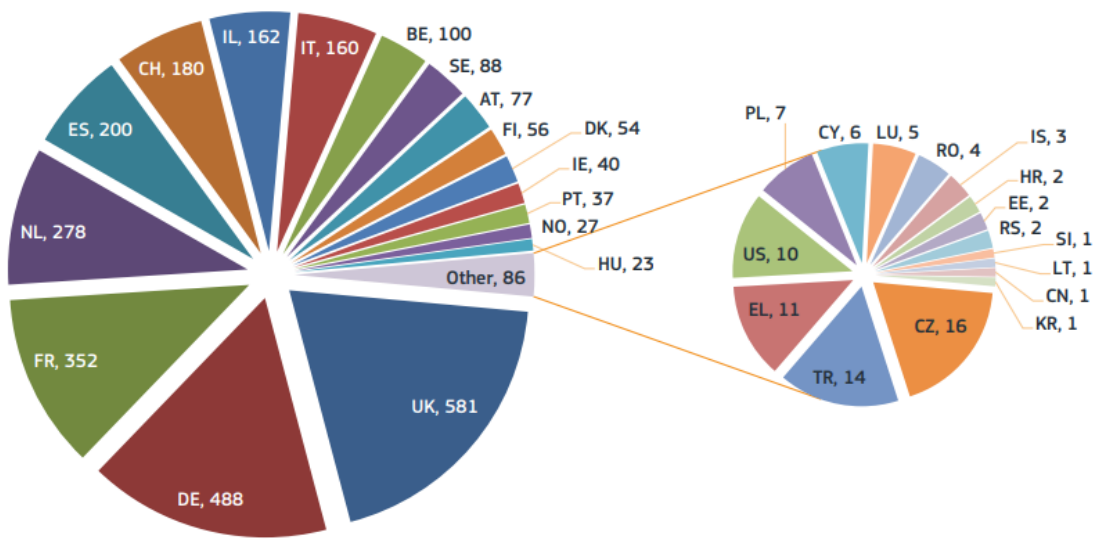

Izvor: European Commission (2018b), Figure 1.4-A.6, str. 161

Značenju ovoga pokazatelja pridonosi informacija kako su Hrvati na inozemnim institucijama nositelji 19, a u domovini 3 ERC granta/projekta (MZO, 2018). Tom činjenicom uzroci nepovoljnog stanja postaju jasniji. Nije dakle primaran uzrok kvaliteta istraživača i relevantnost istraživačkih ciljeva. Hrvatski istraživači u inozemstvu u jakoj konkurenciji domicilnih dobivaju elitne europske projekte. Radeći na vrhunskoj suvremenoj opremi i u poticajnom institucionalnom okruženju, oni bjelodano postižu vrhunske rezultate. Istodobno se ti rezultati ne postižu u hrvatskim uvjetima. To je očekivan ishod kada se analizira kvantiteta i kvaliteta kapitalne istraživačke opreme, njezina koncentracija i dostupnost te stupanj zastarjelosti i model održavanja. Prema raspoloživim podacima hrvatske znanstvene institucije raspolažu s 83 komada kapitalne istraživačke opreme ukupne vrijednosti veće od 181 milijun kuna (Tablica 3). Nacionalna kapitalna istraživačka oprema vrijedna oko 24 milijuna eura sama po sebi nije dovoljno relevantna infrastruktura koja bi mogla privući elitna europska sredstva koja potiču „cutting edge“ istraživanja bazirana na najsuvremenijoj opremi obično visoke vrijednosti ${ }^{24}$. Pored toga koncentracija gotovo $3 / 4$ vrijednosti kapitalne opreme u četirima znanstvenima institucijama, odnosno gotovo $1 / 2 \mathrm{u}$ Institutu Ruđer Bošković ima dodatan negativni utjecaj. Naime u situaciji neriješenih troškova „hladnoga pogona“ (održavanje, servisiranje, plaće operatora opreme, eksperimentalni materijali), financiranje uglavnom pada na teret troškova redovite djelatnosti matične institucije. To sa svoje strane često

${ }^{24}$ Hrvatska namjerava prema „Indikativnoj listi projektnih prijedloga za znanstvenu infrastrukturu za Europski fond za regionalni razvoj 2014-2020“, sredstvima EU, bitno unaprijediti stanje kapitalne opreme (vidi: MZOS (2014) Plan razvoja istraživačke $i$ inovacijske infrastrukture u Republici Hrvatskoj, str 40, Dodatak 2). Kasnijim širenjem Indikativne liste i osnivanjem 13 znanstvenih centara izvrsnosti znatno su povećani prvobitni iznosi, realizacija kojih se planira od 2018. 
ograničava dostupnost opreme istraživačima iz ostalih (oko 100) znanstvenih i znanstveno obrazovnih organizacija.

Tablica 3. Kapitalna oprema vrijednosti iznad 1,000.000,00 kuna

\begin{tabular}{|l|c|r|c|r|}
\hline \multicolumn{1}{|c|}{ Naziv institucije } & $\begin{array}{c}\text { Broj komada opreme } \\
\text { iznad 1 mil kuna }\end{array}$ & $\%$ & $\begin{array}{c}\text { Nabavna } \\
\text { vrijednost } \\
\text { (milijuni kn) }\end{array}$ & $\%$ \\
\hline Sveukupno & 83 & 100 & 181 & 100 \\
\hline 1. IRB & 23 & 28 & 79 & 43 \\
\hline $\begin{array}{l}\text { 2. PMF Sveučilišta u } \\
\text { Zagrebu }\end{array}$ & 9 & 11 & 25 & 14 \\
\hline $\begin{array}{l}\text { 3. Medicinski fakultet } \\
\text { Sveučilišta u Rijeci }\end{array}$ & 9 & 11 & 11 & 6 \\
\hline $\begin{array}{l}\text { 4. Medicinski fakultet } \\
\text { Sveučilišta u Zagrebu }\end{array}$ & 49 & 59 & 172 & 73 \\
\hline Ukupno 1-4 & & 10 & 17 & 9 \\
\hline
\end{tabular}

Izvor: MZOS (2014)

Inovacije. Relevantna analiza niske inovativnosti i malog broja inovacija $u$ Hrvatskoj, nužno mora početi od potražnje gospodarskih subjekata za I\&R i inovativnim aktivnostima. Potražnja je pak uvelike zadana strukturom odnosno ekonomskom/financijskom snagom poduzeća da ulažu u I\&R i ustrojavaju vlastite istraživačke jedinice. Ona u Hrvatskoj iznosi niskih 0,38\% BDP-a, stavljajući nas na 24. mjesto u EU, „ispred“ Latvije, Cipra i Rumunjske (Eurostat, 2015). Tehnološki zaostale i u prosjeku usitnjene hrvatske tvrtke objektivno ne mogu snositi troškove istraživanja i razvoja. Tome u prilog govori podatak kako se iznosom od oko 500 milijuna kuna subvencija odnosno poreznih olakšica za I\&R koristi 160 do190 tvrtki. Međutim, svega je 10 do 15 tvrtki u Hrvatskoj s vlastitim istraživačkim centrima, sposobnima sustavno emitirati inovacije. To zorno potvrđuju podaci prema kojima šest kompanija koristi $72 \%$ odnosno blizu $3 / 4$ od spomenutih 500 milijuna kuna, pri čemu 2 multinacionalne kompanije koje posluju u Hrvatskoj koriste 67\% odnosno 2/3 (Tablica 4). 
Tablica 4. Pregled poreznih obveznika koji su u prijavi poreza na dobit (PD obrascu) za 2011. i 2012. godinu iskazali državnu potporu za istraživačko-razvojne projekte (rb.

34.2. PD obrasca)

\begin{tabular}{|c|c|c|c|c|}
\hline & 2011 & & 2012 & \\
\hline KORISNICI & mil.kn. & $\%$ & mil.kn & \\
\hline $\begin{array}{l}\text { ERICSSON NIKOLA } \\
\text { TESLA D.D. }\end{array}$ & 151 & 34 & 136 & 27 \\
\hline PLIVA HRVATSKA D.O.O. & 100 & $\begin{array}{l}(56 \%) \\
22\end{array}$ & 202 & $\begin{array}{l}(67 \%) \\
40\end{array}$ \\
\hline BANKE & 21 & 5 & 12 & 2,4 \\
\hline PODRAVKA/BELUPO & 12 & 2,6 & 8 & 1,6 \\
\hline KONČAR & 22 & 5 & 20 & 4 \\
\hline M SAN/KING & 11 & $\begin{array}{l}(71 \%) \\
2,4\end{array}$ & 6 & $\begin{array}{l}(72 \%) \\
1\end{array}$ \\
\hline UKUPNO & $\begin{array}{l}450 \\
189 \text { KORISNIKA }\end{array}$ & 100 & $\begin{array}{l}505 \\
166 \\
\text { KORISNIKA }\end{array}$ & \\
\hline
\end{tabular}

Izvor: Ministarstvo financija RH, Porezna uprava (2014)

Među bitnim uzrocima poslovno-organizacijske insuficijentnosti hrvatskih tvrtki za intenzivniju inovativnu aktivnost jest činjenica kako je Hrvatska umjesto ,prirodne tercijarizacije“ i relativne deindustrijalizacije doživjela drastičnu i naglu apsolutnu deindustrijalizaciju bez potrebnoga restrukturiranja i modernizacije. Strategija pametne specijalizacije (S3) to posredno evidentira u niskoj zaposlenosti od 5000 do 10000 ljudi u 5 ključnih sektora novoga inovativnoga razvoja (Vlada RH, 2016).

Posljedice niske tehnološke razine i ovakva stanja potražnje poslovnoga sektora za inovativnom aktivnošću među ostalim su i sljedeće:

- 4,34 patentne prijave na milijun stanovnika, što Hrvatsku stavlja na pretposljednje (ispred Rumunjske) mjesto među članicama EU (Grafikon 5.).

- $\quad$ visoki troškovi kao posljedica niskog intenziteta inovacijske aktivnosti razvidnu četiri puta višim hrvatskim troškovima u odnosu na njemačke, odnosno četiri puta višim izdacima po patentu registriranom u SAD-u (Grafikon 6). 
Grafikon 5. Broj patenata na milijun stanovnika (2013.)

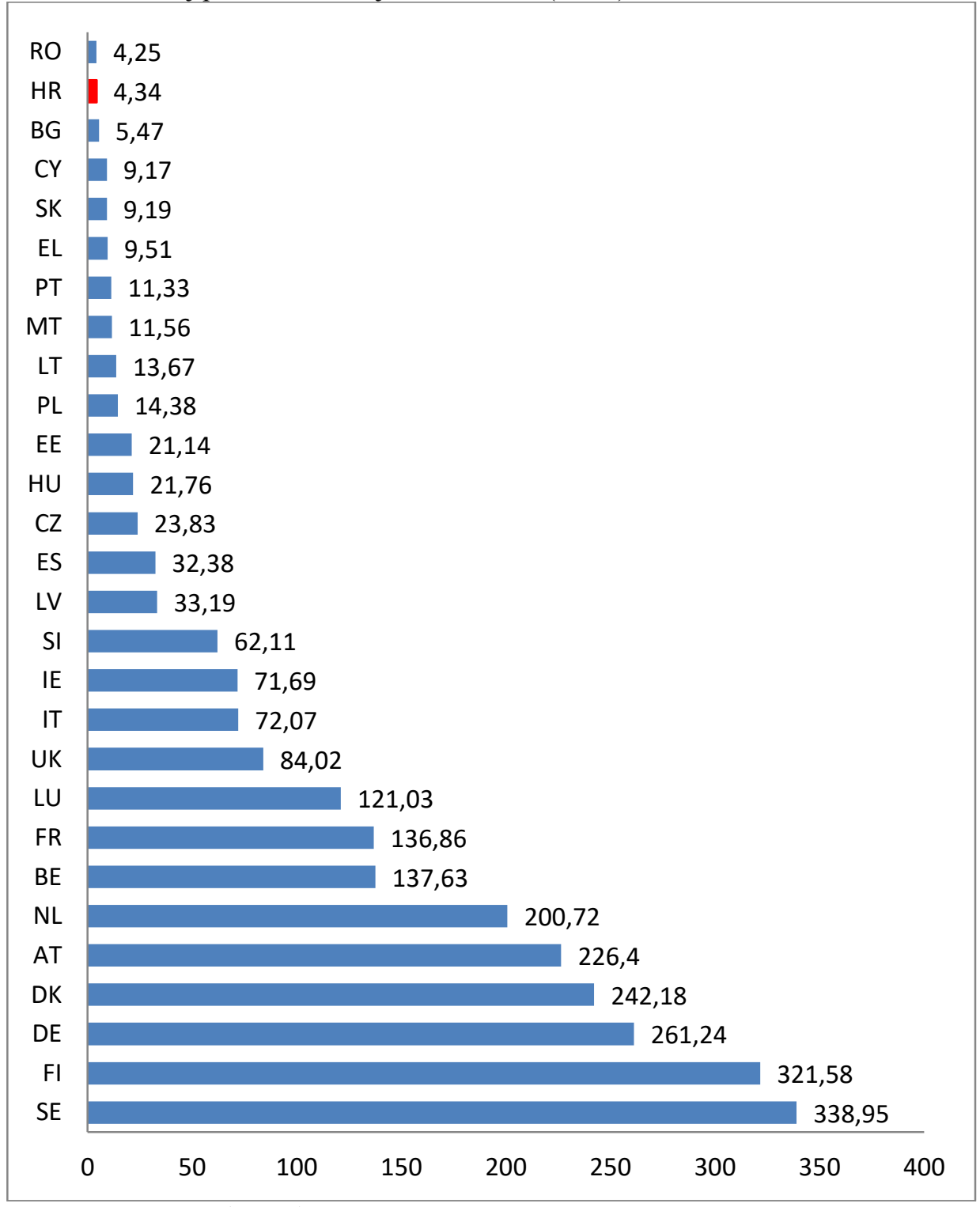

Izvor: Eurostat (2019c) 
Grafikon 6. Potrebna investicija po patentu registriranom u SAD-u

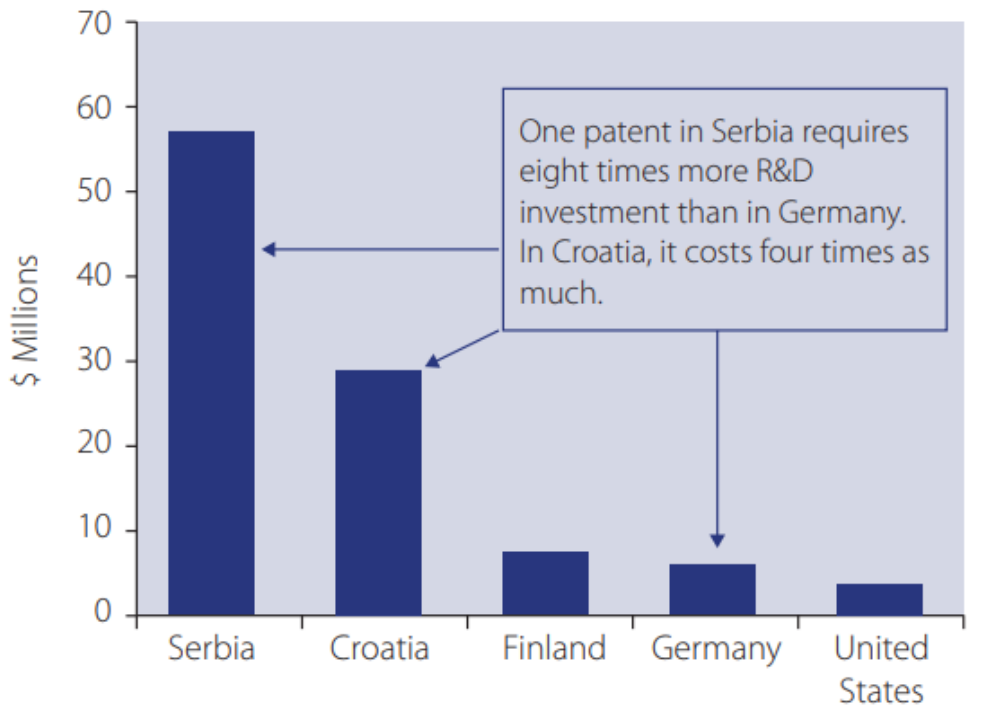

Izvor: World Bank (2013)

Povratan učinak narečene inovacijske slike i njezinih uzroka relativno je niska pozicija u globalnoj konkurentnosti, koja je pak u skladu s ekonomskom snagom nacionalne ekonomije. Hrvatska se po ekonomskoj snazi odnosno prema vrijednosti BDP-a iskazanoj u američkim dolarima prema nominalnom tečaju nacionalnih valuta prema trima svjetskim listama (Međunarodni monetarni fond - IMF, Svjetska banka WB i Ujedinjeni narodi - UN) nalazi između 76. i 78. mjesta (Wikipedia, 2019). To mjesto gotovo u cijelosti odgovara 74. mjestu prema Globalnom indeksu konkurentnosti Svjetskoga ekonomskoga foruma (World Economic Forum, 2019). Tu „ravnotežnu“ sliku narušava nizak (106.) rang u inovacijama unutar Globalnoga indeksa konkurentnosti kao „potvrda“ nepovoljne inovacijske aktivnosti. Najveći „doprinos“ nepovoljnom inovacijskom rangu daje:

- Vladina nabava naprednih tehnoloških proizvoda - 134,

- Kapacitet za inovacije - 120,

- Suradnja znanosti i industrije u istraživanju i razvoju - 118,

- Ulaganje poduzeća u istraživanje i razvoj - 97,

- a potom slijede,

- Dostupnost znanstvenika i inženjera - 95

- $\quad$ i „najmanji“ problem

- Kvaliteta znanstveno-istraživačkih institucija - 66

Uočeno stanje upućuje na potrebu „obrnutoga“ pristupa od uobičajenoga prema kojemu se potražnja gospodarstva i ,unutarnja“ razvojna potreba poduzeća da održi i 
unaprijedi konkurentnost materijalizira u ulaganjima $\mathrm{u} I \& \mathrm{R}$ i rast inovacija. Hrvatska situacija zahtijeva, među ostalim, i (samo)osposobljavanje znanosti ne samo da čeka „narudžbe“ iz prakse, nego i da (dodatnim transparentnim financiranjem) „kreira“ potražnju za istraživačkim projektima koji unapređuju poslovanje i konkurentnost, okupljajući poduzetnike u centrima izvrsnosti, centrima kompetencije, znanstvenotehnologijskim parkovima, klasterima, spin-off i spin-out pothvatima i drugim oblicima. Ovako neizravno -,,subvencioniranje“- i podizanje konkurentnosti nacionalnoga gospodarstva predviđeno je i Strategijom pametne specijalizacije i dopušteno EU pravilima slobodne tržišne utakmice.

\subsubsection{Učinkovitost hrvatskih ulaganja u znanost}

Analizirajući učinkovitost hrvatskih ulaganja u znanost, Europska komisija, pored već spomenute niske razine i padajućega udjela javnih ulaganja u znanost 2008. 2015., upućuje na rezultirajuću nepovoljnu strukturu odnosno niski udjel izdataka za „,infrastrukturne“ sektore u proračunskim izdacima, koji su preduvjet suvremenoga razvoja: "...trendovi indiciraju da se udjel izdataka za promet i obrazovanje smanjio $\mathrm{u}$ razdoblju 2008. - 2015.“ (European Commission 2018a: 20).

Raščlanjujući učinkovitost hrvatskih javnih/proračunskih izdataka, Europska se komisija oslanja na poredbeno Izvješće o znanstvenim, istraživačkim i inovacijskim performansama EU (European Commission, 2018b). EK naglašava kako su hrvatski rezultati u učinkovitosti korištenja kompatibilni odnosno u suglasju s rezultatima peer skupine zemalja (Poljska, Latvija, Slovačka,) dakle sa zemljama sa sličnim investicijama u znanost u odnosu na BDP (Grafikon 7). Međutim, u usporedbi s EU prosjekom Hrvatska ima vrlo slabe rezultate u kvaliteti znanstvenoga outputa (European Commission 2018a: 43) jer među 10\% svjetski najcitiranijih publikacija kao postotkom ukupnih znanstvenih publikacija ima 4,1 u odnosu na EU prosjek od 11,1. 
Grafikon 7. Najboljih $10 \%$ znanstvenih radova kao funkcija udjela javnih izdataka za istraživanje i razvoj u BDP-u, 2014. (citatno razdoblje 2014. - 2016.)

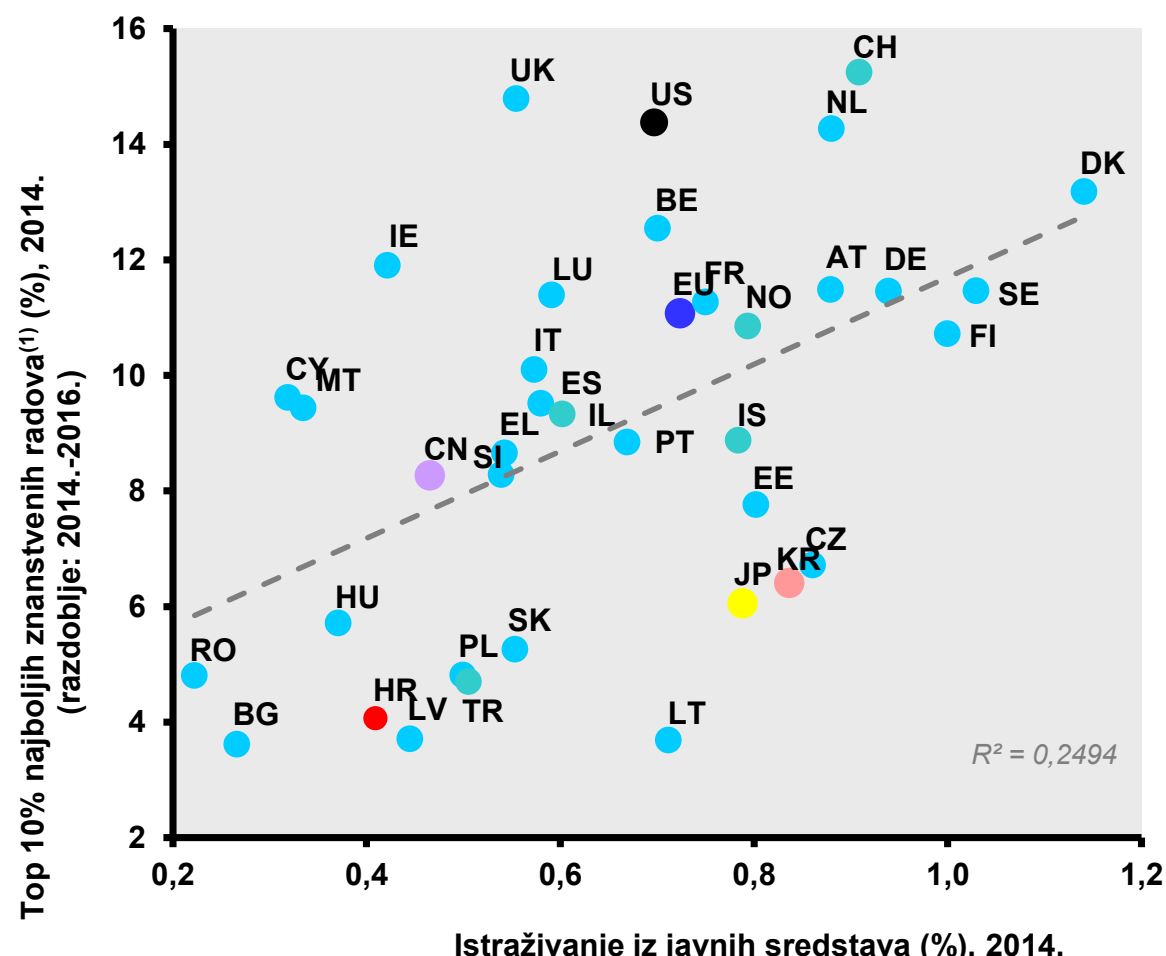

Izvor: European Commission (2018b), Figure I.4-A.7, str. 162

Spoznaja kako je hrvatska znanstveno-istraživačka produkcija „u skladu“ s „tranzicijskim“ susjedima u Srednjoj Europi, ali i kako kvalitetom zaostaje za EU prosjekom važna je za početnu ocjenu stanja kao i sugestija Europske komisije kako bez promjene u strukturi proračunskih izdataka u korist prometa i znanosti i obrazovanja, Hrvatska ne može ostvariti održivi rast.

Zato je znanstveno-istraživačkoj produktivnosti Hrvatske kao male zemlje potrebno posvetiti dodatnu pozornost. Naime, kako javno izdvajanje za znanstvena istraživanja obuhvaća sva znanstvena područja, to stavlja u različiti položaj veće u odnosu na manje zemlje, odnosno „veće“ u odnosu na „manje“ jezike, u pojedinim znanstvenim područjima.

U pojedinim znanstvenim područjima manje su zemlje odnosno njihove publikacije na materinskom jeziku od početka zakinute glede mogućnosti (konkurentnosti) publiciranja u svjetskim visoko citiranim časopisima. To se osobito odnosi na društvene i humanističke znanosti. Tako primjerice radovi koji se bave hrvatskim povijesnim, ekonomskim, pravnim ili sociološkim temama bitnima za hrvatski 
društveni, kulturni i gospodarski razvoj i nacionalni identitet i koji su pri tom objavljeni na hrvatskom jeziku, ne moraju biti zanimljivi široj svjetskoj znanstvenoj javnosti, pa je i mogućnost njihove objave u svjetskim časopisima u startu niža. No to se može odnositi i na prirodoslovno i/ili biotehničko područje kada istražuju pojave ili procese povezane sa specifičnostima hrvatskoga razvoja. To je za zemlju koja je kao Hrvatska relativno nedavno stekla punu nacionalnu slobodu i državnu samostalnost osobito značajno pitanje kojemu je potreban razuman i stručno ravnotežan pristup. Tako je u znanstvenoj produkciji važno biti međunarodno vidljiv i kvalitetu dokazivati objavom u visokocitiranim svjetskim časopisima, što podrazumijeva i objavljivanje na svjetskim (uglavnom engleskom) jezicima. No isto tako je iznimno važno objavljivati znanstvene radove i na hrvatskom jeziku kako bi se iznašli hrvatski termini za nove znanstvene pojave i procese. Jedino tako materinski jezik ostaje -,,živ“- i ne tone u lokalno narječje. Takva zadaća - objave u vrhunskim svjetskim časopisima na svjetskim jezicima i razvoj visoko kvalitetne znanstvene produkcije na materinskom jeziku - mora biti uzeta u obzir pri međunarodnim usporedbama, a osobito se mora uzeti u obzir kada se utvrđuju politika i kriteriji financiranja znanstvenih istraživanja.

$\mathrm{U}$ tom je smislu podobna međunarodna analiza koja uspoređuje prirodne znanosti koje imajući uglavnom zajedničke (identične) predmete istraživanja, međusobno komuniciraju univerzalnim jezikom struke (nekoć latinskim, a danas engleskim). Naime usporedbe su dodatno objektivizirane kada su baza usporedbe „objavljivi“ radovi u prirodnim znanostima (na engleskom jeziku) umjesto ukupne znanstvene produkcije koja uključuje i međunarodno „neobjavljive“ radove (na hrvatskom jeziku u društvenim znanostima).

Takvu analizu poduzima svjetski visoko citiran časopis Nature objavljivanjem Nature Global Indexa (NGI), kojim se uspoređuje znanstvena kvaliteta i produktivnost 100 zemalja u prirodnim znanostima temeljem objavljenih radova u 68 najkvalitetnijih svjetskih časopisa u prirodnim znanostima. Pri tom se koriste dva pokazatelja. Prvi je Ukupan zbroj članaka („AC“ - article count). Drugi je „Ponderirani frakcijski zbroj“ (WFC - Weighted Fractional Count) (Nature Index Global, 2014). WFC se koristi kako bi se izbjegao prenaglašen utjecaj članaka iz područja fizike i astrofizike. Naime, četiri časopisa iz tih disciplina objavljuju oko $50 \%$ svih radova u časopisima iz fizike - oko pet puta više od drugih disciplina. Stoga se podaci za astrofiziku i fiziku prikupljaju na isti način i njima se pridružuje jedna petina pondera $(0,2)$ koja se pridružuje ostalim člancima (Nature Index, 2017).

NGI 2014, koji za 2013 rangira 100 zemalja prema vrijednosti WFC-a, stavlja Hrvatsku na 43. mjesto s vrijednošću AC-a od 105 i WFC-a od 22,66.

Kako bismo usporedili efikasnost objavljenih istraživanja Hrvatske i ostalih članica EU prilagodili smo tablicu NGI-ja samo za zemlje članice EU, među kojima je Hrvatska rangirana na 19. mjesto (Nature Index Global, 2014). Istodobno, prema statistici EU Hrvatska se s udjelom javnih Bruto izdvajanja za istraživanje i razvoj (GERDp-Gross Expenditure for Research \& Development -public) od 0,4\% BDP-a nalazi na 23 mjestu među članicama EU (Eurostat, 2015) (Tablica 5.). 
Tablica 5. Rangiranje članica EU efikasnosti javnih ulaganja (GERDp) u znanstvena istraživanja $\left(k_{G E R D p}\right)$

\begin{tabular}{|c|c|c|c|c|}
\hline & Zemlja & NGI- rang ${ }^{25}$ & GERDp-rang & $k_{G E R D p}$ \\
\hline 1 & Ujedinjeno Kraljevstvo & 2 & 16 & 8,00 \\
\hline 2 & Njemačka & 1 & 4 & 4,00 \\
\hline 3 & Italija & 4 & 15 & 3,75 \\
\hline 4 & Francuska & 3 & 9 & 3,00 \\
\hline 5 & Španjolska & 5 & 14 & 2,80 \\
\hline 6 & Poljska & 11 & 20 & 1,82 \\
\hline 7 & Mađarska & 17 & 24 & 1,41 \\
\hline 8 & Belgija & 8 & 11 & 1,38 \\
\hline 9 & Irska & 16 & 22 & 1,38 \\
\hline 10 & Rumunjska & 20 & 27 & 1,35 \\
\hline 11 & Bugarska & 21 & 26 & 1,24 \\
\hline 12 & Hrvatska & 19 & 23 & 1,21 \\
\hline 13 & Grčka & 15 & 18 & 1,20 \\
\hline 14 & Slovenija & 18 & 19 & 1,06 \\
\hline 15 & Cipar & 26 & 25 & 0,96 \\
\hline 16 & Portugal & 13 & 12 & 0,92 \\
\hline 17 & Nizozemska & 6 & 5 & 0,83 \\
\hline 18 & Latvija & 27 & 21 & 0,78 \\
\hline 19 & Slovačka & 23 & 17 & 0,74 \\
\hline 20 & Austrija & 10 & 6 & 0,60 \\
\hline 21 & Luksemburg & 25 & 13 & 0,52 \\
\hline 22 & Češka & 14 & 7 & 0,50 \\
\hline 23 & Litva & 24 & 10 & 0,42 \\
\hline 24 & Estonija & 22 & 8 & 0,36 \\
\hline 25 & Švedska & 7 & 2 & 0,29 \\
\hline 26 & Finska & 12 & 3 & 0,25 \\
\hline 27 & Danska & 9 & 1 & 0,11 \\
\hline
\end{tabular}

Izvor: obrada autora prema Global Nature Index 2014 i Eurostat news release 209/2015

${ }^{25}$ NGI ne navodi Maltu pa je zbog konzistentnosti izostavljena iz usporedbe 
Koeficijent efikasnosti javnih ulaganja u znanost i istraživanja $\left(k_{G\left(k_{G E R D p}\right)}\right)^{26}$ polazi od pretpostavke da je njegova jedinična vrijednost prema kojoj je rang izdvajanja jednak rangu u Nature globalnom indeksu, ,normalna“ ili očekivana vrijednost. Svaka vrijednost veća od 1 čini izdvajanje efikasnim pa što je koeficijent viši to je ulaganje (izdvajanje) efikasnije. Obrnuto, što je koeficijent niži od 1 odnosno bliži nuli, to je ulaganje neefikasnije. Jedinična efikasnost prikazana je crvenom crtom (Grafikon 5). Takvoj su efikasnosti najbliži Slovenija (rang prema NGI 18 a prema javnim ulaganjima GERDp ima rang 19) te Cipar (NGI rang 26 a GERDp rang 25). Te su zemlje prikazane crnim stupcima. Pojednostavljeno, njihov rang prema Nature indeksu gotovo odgovara rangu prema udjelu izdvajanja za I\&E u bruto domaćem proizvodu. Plavi stupci lijevo od jediničnih vrijednosti („,crnih“ stupaca Cipra i Slovenije) predstavljaju zemlje koje financijski efikasno ulažu, dok stupci desno predstavljaju zemlje koje financijski neefikasno ulažu u znanstvena istraživanja. Prema tom pokazatelju, Hrvatska s oskudnim ulaganjima relativno efikasno ulaže (21\% iznad jedinične vrijednosti, ,crveni“ stupac) i zauzima 12 mjesto prema financijskoj efikasnosti ulaganja među članicama EU u prirodnim znanostima (Grafikon 8.).

Grafikon 8. Rang članica EU prema $k_{G E R D p}$

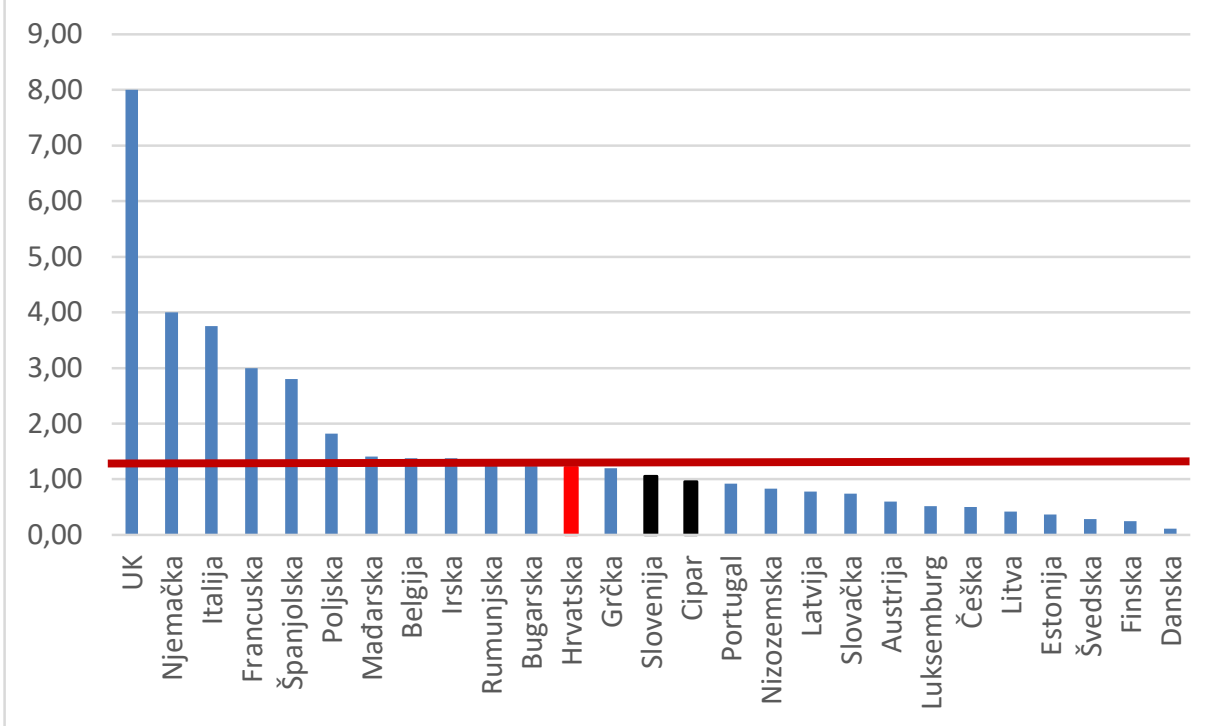

Izvor: obrada autora prema Global Nature Index 2014 i Eurostat news release 209/2015

${ }^{26} k_{G E R D_{p}}=1+\frac{\left(G E R D_{p_{R}}-N G I_{R}\right)}{N G I_{R}}$ 


\subsection{Visoko obrazovanje}

Značenje osobito visokoga obrazovanja za opstanak i prosperitet hrvatskoga i svakoga drugog društva čini odgovornost polazištem ocjene stanja. Tu odgovornost čine dvije komponente. Prva je individualna odgovornost prema investitorima i snositeljima rizika izbora obrazovnoga programa-struke i zapošljivosti odabrane kvalifikacije. Druga je društvena odgovornost za kvalitetu ishoda učenja i njihov utjecaj na opstojnost $i$ društveni, gospodarski, kulturni i umjetnički boljitak vlastite države i njezine međunarodne civilizacijske stečevine.

Individualna odgovornost. Hrvatski su porezni obveznici praktično jedini investitori kojima je znanstvena zajednica visokoga obrazovanja odgovorna i za koga „proizvodi“. Dakle sadašnji i donedavni zaposlenici, koji se najmanje tri puta pojavljuje kao investitor u sustav znanosti i visokog obrazovanja;

- prvi put kao sadašnji (oko 1,400.000 ili donedavni oko 1,100.000) zaposlenici/umirovljenici odnosno proizvođači-stvaratelji koji iz svojega dohotka obvezno izdvajaju i doprinos za obrazovanje (u što je uključena i znanost),

- $\quad$ drugi put njih oko 2,500.000 s obiteljima kada kao zadnji potrošači u lancu plaćaju puni iznos PDV-a za kupljenu robu i usluge, iz čega se također proračunski ulaže i u znanost i visoko obrazovanje,

- treći put kao skrbnici koji studentu osiguravaju životne uvjete (stanovanje i druge egzistencijalne potrebe $u$ razdoblju investiranja-obrazovanja), osiguravajući mu ,poček“ na povrat od ulaganja u obrazovanje.

Ukratko, oni su tvorci platežno sposobne potražnje za obrazovnim programima. Zato su načelno njihove preferencije glavni i tržišni i društveni signal za formiranje ponude a time i prvi bitan kriterij utvrđivanja upisnih kvota. Onaj tko plaća ima pravo izbora.

Ti isti porezni obveznici praktično su (kao roditelji i njihova djeca studenti) jedini ,potražitelji/potrošači“ obrazovnih programa, a time i jedini snositelji rizika zapošljivosti struke i kvalifikacije koju su stekli i to dva puta:

- $\quad$ prvi put - obiteljski financirajući individualne egzistencijalne troškove tijekom razdoblja nezaposlenosti,

- drugi put - doprinosom za nezaposlene, financirajući opće troškove nacionalne nezaposlenosti.

Za ocjenu stanja u sustavu važno je naglasiti kako ni sveučilišta ni njihovi nastavnici, ni zavodi za zapošljavanje ni njihovi stručnjaci, ni MZO i njegovi zaposlenici, pa ni poduzetnici i njihove trenutačno iskazane potrebe, ne snose nikakvu materijalnu ili moralnu odgovornost za moguću nezaposlenost.

Pojednostavljeno onaj tko snosi rizik ima slobodu (informiranoga) riskiranja u izboru budućega zanimanja i zato ta sloboda izbora mora biti evidentirana i u kriterijima financiranja prema programskim ugovorima.

Društvena odgovornost. Oko 10000 u sustavu istraživački aktivnih doktora znanosti čini oko $0,25 \%$ ili $1 / 4$ postotka hrvatskoga stanovništva. Uz sve mane $i$ vrline, to je „elita“ na kojoj počiva velika stručna odgovornost dostizanja životnih uvjeta 
razvijenoga dijela Europe u razumnom roku radnoga vijeka sljedeće generacije. Među ostalim, odgovornost proizlazi i iz triju razloga koji se ukupno mogu procijeniti na oko 55 milijarda kuna;

- 20 godina školovanja - 5 milijarda kuna. Prosječno 20 godina školovanja doktora znanosti društvena je investicija od oko 500.000 odnosno ukupno oko 5 milijarda kuna,

- 20 godina radnoga iskustva - 36 milijarda kuna. Prosječno 20 godina radnoga iskustva doktora znanosti $\mathrm{s}$ prosječnim (proračunskim) mjesečnim bruto primanjima od 15.000 kuna društvena je investicija od ukupno oko 36 milijarda kuna

- $728000 \mathrm{~m}^{2}$ nastavno opremljenog prostora - 13,5 milijarda kuna. Evidentiranih $728000 \mathrm{~m}^{2}$ nastavno opremljenoga prostora (po cijeni od prosječno 18,5 tisuća $\mathrm{kn} / \mathrm{m}^{2}$ ) društvena je investicija od oko 13,5 milijarda kuna

Ovaj brojčano sićušan a formalno najobrazovaniji segment hrvatskoga pučanstva zato je intelektualno i stručno najodgovorniji za formuliranje razvojnih izbora.

\subsubsection{Dinamika hrvatskoga visokoga obrazovanja}

Hrvatsko državno osamostaljenje i stvaranje suverene demokratske države nakon 1990., stvorili su povoljno okruženje za razvoj visokoga obrazovanja. Broj studenata više je nego udvostručen: od gotovo 70000 na 157000 . Uspješnost studiranja također je povećana. Broj studenata koji diplomiraju je utrostručen: od 10 tisuća na više od 33 tisuće. Broj doktora znanosti i doktorskih kandidata povećan je za 53\%. Osobito je dojmljiv obuhvat stanovništva u studentskoj dobi (19 - 23) tercijarnim obrazovanjem, koje je poraslo od 1/5 (22\%) na gotovo $2 / 3$ (64 \%) (Tablica 6.).

Tablica 6. Razina obrazovanosti

\begin{tabular}{|r|r|r|r|r|r|r|l|}
\hline & \multicolumn{1}{|l|}{$\begin{array}{l}\text { Broj } \\
\text { stanovnika } \\
\text { u dobi 19- } \\
\text { Godina godine }\end{array}$} & $\begin{array}{l}\text { Ukupan } \\
\text { broj } \\
\text { studenata }\end{array}$ & $\begin{array}{l}\text { Obuhvat } \\
\text { tercijarnim } \\
\text { obrazovanjem }\end{array}$ & & Diplomirani & $\begin{array}{l}\text { Završena } \\
\text { srednja } \\
\text { skkola }\end{array}$ & $\begin{array}{l}\text { Doktori } \\
\text { znanosti i } \\
\text { doktorandi u } \\
\text { obrazovnom } \\
\text { procesu }\end{array}$ \\
\hline 1990 & 315.888 & 69.021 & $22 \%$ & 31.007 & 10.388 & 42.408 & - \\
\hline 2000 & 305.631 & 100.297 & $33 \%$ & 41.524 & 13.510 & 49.081 & 7.771 \\
\hline 2010 & 261.658 & 148.616 & $57 \%$ & 58.750 & 32.278 & 45.551 & 11.217 \\
\hline 2014 & 247.141 & 157.827 & $64 \%$ & 58.889 & 33741 & 46934 & 11.912 \\
\hline
\end{tabular}

Izvor: DZS (2009)

Učinjeni su iskoraci u kvaliteti prema rezultatima akreditacije visokih učilišta provedenoj prema međunarodnim sustavima kvalitete i temeljem nalaza međunarodnih recenzenata. Naglasak je na uglavnom zadovoljavajućoj kvaliteti programa i nastavnika, a nezadovoljavajući su međunarodna suradnja (mobilnost) i objavljivanje u inozemnim publikacijama (AZVO, 2015). 
Učinjen je i pomak u strukturi studija tako da je udjel studenata koji studiraju u društveno-humanističkom području u tom razdoblju smanjen s $59 \%$ na $54 \%{ }^{27}$. No treba napomenuti kako taj postotak uključuje, osim javnih koja se financiraju iz proračuna $\mathrm{i}$ privatna visoka učilišta. Privatna visoka učilišta kojima se broj studenata povećao za $46 \%$ u ovom razdoblju (od 10924 na 15 985) (AZVO, 2019) velikom su većinom programa u društveno-humanističkom području (oko $3 / 4$ studenata) gdje dominiraju programi poslovne ekonomije. Kada se to uzme $u$ obzir tada se omjer javnog financiranja društvenih studija dodatno mijenja. Primjerice, na četirima „velikima“ javnima ekonomskim fakultetima (Osijek, Split, Rijeka i Zagreb) 2009. studiralo je 19.371 student, a 2014.godine 12.571 student (DZS, 2009). Odnosno, na tim je fakultetima 2014. bilo 52\% manje studenata nego 2009. godine.

Potrebu kritičke analize pozitivnih rezultata visokoga obrazovanja valja staviti u kontekst izrazito nepovoljnih trendova u financiranju, koji osobito u razdoblju krize bitno utječu kako na kvalitetu tako i na položaj nacionalnoga sustava u europskome okruženju jer je:

- državni proračun je povećan $(+8,5 \%)$,

- proračun MZO-a za visoko obrazovanje i znanost u njemu je smanjen (-4,5\%),

- broj studenata na fakultetima je povećan $(+11,6 \%) \quad$ (Tablica 7.)

Tablica 7. Izdaci za znanost i visoko obrazovanje (u mil. kn)

\begin{tabular}{|l|r|r|l|}
\hline & \multicolumn{1}{|c|}{2009.} & \multicolumn{1}{|c|}{2014.} & \\
\hline Proračun Vo+Zn & 4.108 & 3.928 & $(-4,3 \%)$ \\
\hline Državni proračun & 118.000 & 128.000 & $(+8,5 \%)$ \\
\hline Studenti ukupno & 145.263 & 157.827 & $(+8,6 \%)$ \\
\hline Studenti na fakultetima & 112.437 & 125.258 & $(+11,6 \%)$ \\
\hline
\end{tabular}

Izvor: DZS (2014), MZO

\subsubsection{Hrvatski, globalni i EU obrazovni trendovi}

Učinjeno dakako nije niti izbliza dovoljno jer su u globalnim i europskim razmjerima također učinjeni golemi iskoraci kao posljedica svrstavanja obrazovanja i znanosti u ,infrastrukturne“ prioritete o kojima u bitnome ovisi uspješan ukupni rast te osobito rast konkurentnosti.

Europska unija u svojim je strategijskim ciljevima (EU 2013.) među ostalim naglasila znanost i inovacije kao ključan razvojni čimbenik te prioritet podizanja razine obrazovanosti i kvalificiranosti stanovništva (Europska unija, 2013). U visokoj naobrazbi taj se cilj definira kao udjel od $40 \%$ tercijarno obrazovanih u strukturi radne snage u dobi od 25-65 godina, a negdje i više. Štoviše, rast udjela visokoobrazovanoga stanovništva

${ }^{27}$ Izračunano prema AZVO https://www.azvo.hr/hr/visoko-obrazovanje/statistike 
vidi se kao jedan od bitnih elemenata izlaska iz krize 2008. godine, ali i kao bitan element dugoročnoga uspješnoga i održivoga rasta. Ekonomski najuspješnije zemlje EU-a poput Njemačke, u tom smislu najavljuju i povećanje javnih izdataka za visoku naobrazbu (Doolan, Dolenec, Domazet, 2012). Trenutačno je u razvijenome dijelu EU-a udjel visokoobrazovanih u strukturi radne snage oko $30 \%$, a u Hrvatskoj manji od $20 \%$ (Tablica 8.).

Tablica 8. Udjel tercijarno obrazovanih u strukturi radne snage u dobi od 25 do 64 godine

\begin{tabular}{|l|r|r|r|r|}
\hline Zemlja & \multicolumn{1}{|l|}{2002.} & \multicolumn{1}{l|}{2005.} & \multicolumn{1}{l|}{2008.} & \multicolumn{1}{c|}{2011.} \\
\hline EU27 & 20,0 & 22,5 & 24,3 & 26,8 \\
\hline EU25 & 20,5 & 23,1 & 24,8 & 27,4 \\
\hline EU15 & 21,8 & 24,2 & 25,8 & 28,2 \\
\hline Belgija & 28,1 & 31,0 & 32,3 & 34,6 \\
\hline Bugarska & 21,2 & 21,6 & 22,8 & 23,4 \\
\hline Češka & 11,9 & 13,1 & 14,5 & 18,2 \\
\hline Danska & 29,6 & 33,5 & 31,4 & 33,7 \\
\hline Njemačka & 22,3 & 24,6 & 25,4 & 27,6 \\
\hline Mađarska & 14,2 & 17,1 & 19,2 & 21,1 \\
\hline Portugal & 9,4 & 12,8 & 14,3 & 17,3 \\
\hline Rumunjska & 9,8 & 11,1 & 12,8 & 14,9 \\
\hline Slovenija & 15,3 & 20,2 & 22,6 & 25,1 \\
\hline Slovačka & 10,9 & 14,0 & 14,8 & 18,8 \\
\hline Finska & 32,4 & 34,6 & 36,6 & 39,3 \\
\hline Švedska & 26,4 & 29,6 & 32,0 & 35,2 \\
\hline UK & 29,8 & 29,9 & 32,0 & 37,0 \\
\hline Hrvatska & 15,9 & 16,0 & 16,6 & 18,1 \\
\hline
\end{tabular}

Izvor: Eurostat

Dakle, razvojne potrebe „ostatka“ EU diktiraju projekcije i strategije visokoga obrazovanja kojima se neprekidno povećava broj tercijarno obrazovanoga stanovništva, iako razvijenije članice već i sada imaju gotovo dvostruko više tercijarno obrazovanih u strukturi radne snage od Hrvatske.

Iz toga proizlazi jednostavna kvantifikacija: Hrvatska bi trebala imati oko 400.000 više tercijarno obrazovanih nego što ih trenutno ima da bi bila na razini od oko $35 \%$ njihova udjela u strukturi radne snage, koliko otprilike imaju razvijene članice EUa.

Uzroci takvog stanja mogu se dijelom pronaći u komponentama globalnoga rangiranja 50 nacionalnih sustava visokoga obrazovanja koje provodi Melburnski institut za primijenjena socijalna i ekonomska istraživanja (Unversitas 21, 2017), među kojim su 
22 članice EU. Nacionalni sustavi šest članica EU (Cipar, Luksemburg, Latvija, Litva, Estonija, Malta), nisu rangirani među 50 najbolje rangiranih svjetskih sustava. Hrvatska je prema ukupnom rangu na 43. mjestu, pri čemu su Bugarska i Rumunjska iza nje, što znači da je između 28 članica EU, Hrvatska na 20. mjestu.

Ukupan rang rezultat je ponderiranja četiriju komponente:

- Ishodi - Output (40 \%) najznačajnija su komponenta (broj objavljenih znanstvenih radova -ukupno i po stanovniku), prosječan čimbenik odjeka, rangiranje prema Šangajskoj listi, obuhvat populacije u studentskoj dobi tercijarnim obrazovanjem, broj istraživača na milijun stanovnika, nezaposlenost tercijarno obrazovanih $u$ odnosu na nezaposlene sa srednjim obrazovanjem $u$ populaciji 25-64 godine. Upravo je prema toj najznačajnijoj komponenti Hrvatska rangirana na 34. mjesto znatno iznad ukupnoga ranga. Od članica EU iza nje su Bugarska, Rumunjska i Slovačka.

- Povezanost - Connectivity (20 \%) obuhvaća znanstveno-istraživačku vidljivost i odjek (webometrics visibility, webometrics transparency), udjel stranih studenata $\mathrm{u}$ tercijarnom obrazovanju, transfer znanja i udjel zajedničkih publikacija s istraživačima iz gospodarstva. Prema toj komponenti Hrvatska je rangirana na 40. mjesto. Od članica EU iza nje je Poljska, a kao kuriozitet i Rusija, Kina, Brazil i Indija.

Dakle, ta dva kriterija „dižu“ rang Hrvatske iznad ukupnoga ranga, osobito najvažniji ishodi.

- Okruženje - Environment (20 \%) obuhvaća kriterije autonomije i konkurentnosti (omjer javnih i privatnih obrazovnih institucija, udjel žena u studentskoj i nastavničkoj populaciji, kvaliteta podataka, pregled rezultata u financijskoj autonomiji u institucionalnom uređenju). Prema tome pokazatelju Hrvatska je rangirana na 44. mjesto. Od članica EU iza nje su Bugarska i Grčka.

- Financiranje - Resources $\mathbf{( 2 0 \% )}$ obuhvaća ključne financijske pokazatelje (javna/proračunska ulaganja kao postotak BDP-a, ukupna ulaganja u tercijarno obrazovanje kao postotak BDP-a, godišnji izdaci po studentu obračunati u USD prema paritetu kupovne moći - PPP, izdaci institucija tercijarnoga obrazovanja za I\&R kao postotak BDP-a, izdaci u tercijarnom obrazovanju za I\&R po stanovniku obračunati u USD prema paritetu kupovne moći. Prema tom pokazatelju Hrvatska se nalazi na 45. mjestu od 50 zemalja. Od izlistanih članica EU iza nje su Rumunjska i Bugarska.

Kako vidimo, ta dva kriterija „spuštaju“ rang Hrvatske ispod ukupnoga ranga, osobito zbog iznimno važne komponente -financiranja.

Rezultati analize „Universitas 21 “ snagom kompleksnih pokazatelja upućuju na probleme koje je identificirala i prioritete koje je utvrdila EU. U području obrazovanja EU potpuno jasno upozorava kako će ulaganja u kreiranje Europskoga prostora obrazovanja - European Area of Education (EAE), što uključuje i stvaranje „mreže europskih sveučilišta“, tražiti ,benchmark" odnosno izdvajanje minimalno 5\% BDP-a država članica za obrazovanje (od osnovnoga do visokoškolskoga) (European Commission, 2017b). 
Hrvatska se, prema analizi UNESCO-a, s procijenjenih 2,6\% BDP-a prosječnih izdvajanja za cjelokupan sustav obrazovanja, od osnovnoga do visokoga, u razdoblju 2005. -2012., nalazi na 24. mjestu od prikazane 31 zemlje. No među prikazanih 20 članica EU-a, Hrvatska je pretposljednja po visini relativnoga ulaganja u obrazovanje u tom razdoblju (Grafikon 9.). 
Grafikon 9. Izdvajanje za obrazovanje kao postotak BDP-a (PPP) ${ }^{28}$ (prosjek 2005. 2012.)

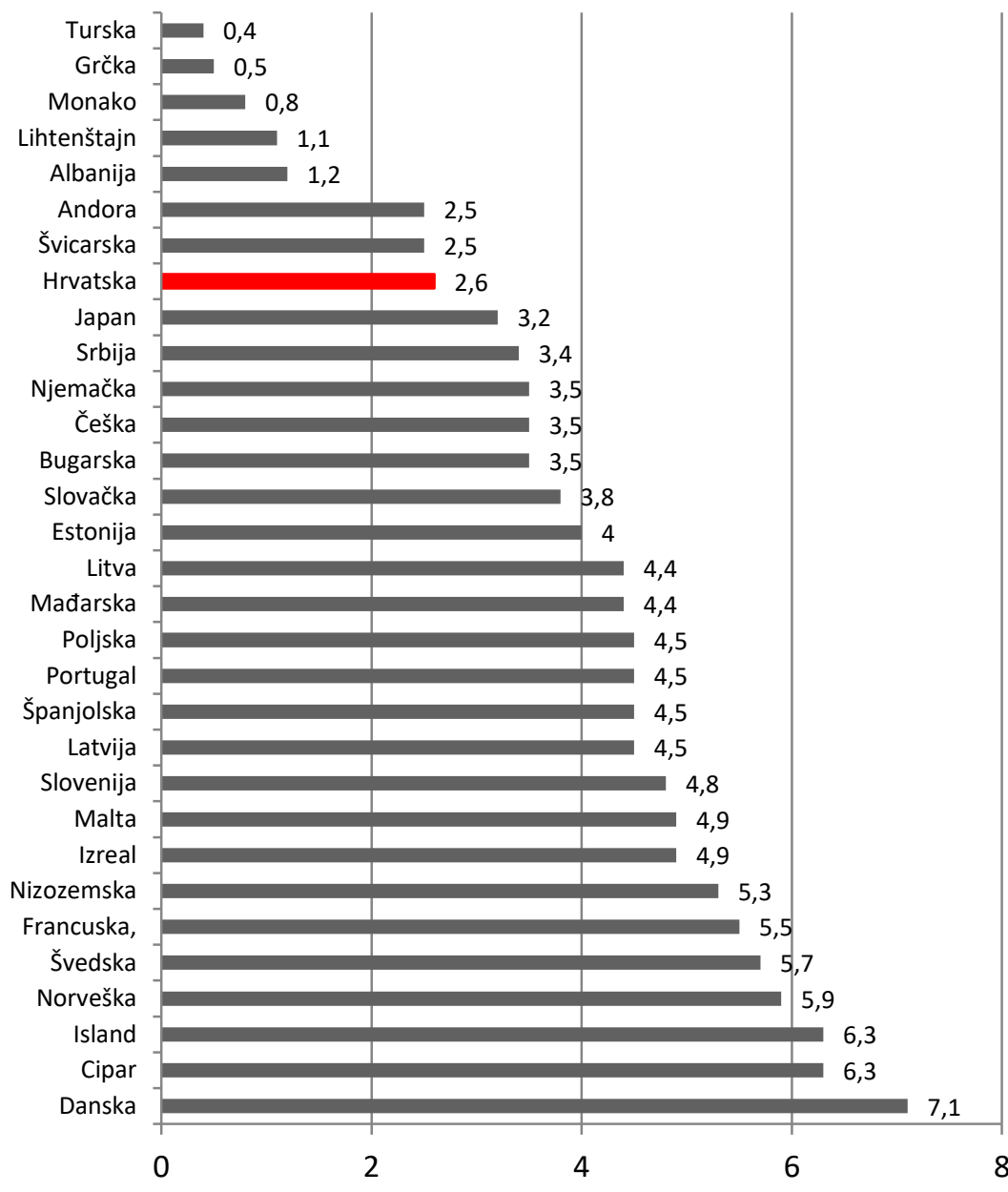

Izvor: Institut za statistiku UNESCO-a (2012). Dostupno na: http://data.uis.unesco.org/

Kao što vidimo, prema trima međunarodnima izvorima, financiranje visokoga obrazovanja i znanosti primaran je problem hrvatskog sustava. Prvi put u prethodnoj analizi ulaganja u znanstvena istraživanja i u I\&R Europske komisije, odnosno Eurostata.

${ }^{28}$ Za detaljniji uvid u izračun hrvatskog Bruto domaćeg proizvoda (BDP) prema paritetu kupovne moći (PPP) prema američkom dolaru (USD) vidi https://www.indexmundi.com/ - izvor CIA World Factbook - 2015 
Drugi ga put identificira sofisticirana analiza Universitas 21 rankinga. Treći put ga spominje analiza UNESCO-a.

Time razvidnim postaje ne samo zaostajanje, nego i divergencija u odnosu na EU trendove kada je riječ o financiranju obrazovanja, osobito visokoga, koji s oskudnim ulaganjima u pravilu daje rezultate malo iznad prosjeka. Tako uspostavljeno dugotrajno funkcioniranje temeljem niske razine financiranja ima gotovo razoran učinak na učinkovitost sustava. Istraživački i obrazovni trendovi pokazuju ozbiljno zaostajanje Hrvatske $\mathrm{s}$ nespornim dugoročnim negativnim učincima na modernizaciju i restrukturiranje hrvatskoga gospodarstva te na inovativnost $\mathrm{i}$ apsorpcijski kapacitet $\mathrm{u}$ primjeni novih tehnologija (Družić, 2018).

\subsubsection{Hrvatski visokoobrazovni sustav i tržište rada}

U strateškom je smislu za uspostavu učinkovitoga i potrebama gospodarskoga razvoja prispodobljenoga sustava visokoga obrazovanja, napose štetna vulgarizacija potrebe o školovanju prema potrebama gospodarstva odnosno tržišta rada u dva smjera.

Vremensko razgraničenje ponude i potražnje na tržištu rada. Prvo, potrebe gospodarskih subjekata za obrazovnim profilima trebale bi se iskazati u njihovoj poslovnoj strategiji i razvojnim planovima za narednih 5-10 godina. Tako oblikovana potražnja mogla bi se onda uravnoteživati s ponudom obrazovnih profila, jer i školovanje budućih stručnjaka traje 4 - 7/9 godina. Međutim uparivati trenutačnu (kratkoročnu) potražnju za radom ovisnu o fazi poslovnoga ciklusa s ponudom koja traži ili 4 godine srednjega $\mathrm{i} /$ ili ukupno 7/9 godina srednjega i visokoga obrazovanja (kako se to sada nameće u dijelu tzv. sektorskih projekcija tržišta rada), ne pripada području racionalne ekspertize.

Druga je teza bitna za ocjenu stanja kako je za rast izvozne konkurentnosti hrvatskoga gospodarstva potrebno reformirati tržište rada odnosno smanjiti cijenu rada. $\mathrm{Na}$ to se nadovezuje stav kako treba obrazovati više stručnjaka s (jeftinijim) srednjim obrazovanjem pa bi svega 50\% srednjoškolaca trebalo nastavljati visoko obrazovanje. Teza kako će se stimuliranjem odnosno smanjenjem troškova rada postojeće gospodarske strukture povećati konkurentnost ima vrlo konkretne posljedice, ponajprije zadržavanje zastarjele gospodarske strukture koja konkurentnost preko $50 \%$ izvoza gradi na bruto satnici od 3,5 a neto od 2,5 eura. Kada se te satnice koje su bitno ispod standarda razvijenih članica EU povežu s troškovima hrvatskoga životnog minimuma (hrana, energenti) blizu njihova prosjeka, ne začuđuje odljev radne snage iz Hrvatske. Istodobno tehnološki i organizacijski zastarjelo gospodarstvo rezultira dugoročnim mjerljivim gubitkom konkurentnosti. U posljednjih 20 godina hrvatsko je gospodarstvo kumulativno uvezlo preko 150 milijardi USD roba više nego je izvezlo, što je 2,5 godišnji BDP. Nije problem u uvozu nego u višku uvoza nad izvozom.

Stoga programiranje sustava treba upraviti prema potrebama budućih zanimanja kao rezultata novih nastajućih tehnologija (FET) i aktualnoga modernoga europskoga tržišta rada, a tek manjim dijelom prema trenutačnim potrebama hrvatskoga tržišta rada.

Ponuda i potražnja za tercijarnim obrazovanjem. Konkretno stanje potražnje za tercijarno obrazovanim kvalifikacijama na hrvatskom tržištu rada pokazuje relativnu stabilnost i parcijalnu ravnotežu ponude i potražnje. Raspoloživi podaci dobrim dijelom 
osporavaju tvrdnje o nezadovoljavajućoj kvalifikacijskoj strukturi tercijarno obrazovanih, među kojima dominiraju društvene znanosti osobito ekonomske i pravne, posredno odgovarajući na dva pitanja.

Pojednostavljeno, prvo je pitanje proizvodimo li (zbog prevelikoga broja studenata u društvenom i humanističkom području) stručnjake za burzu umjesto za tržište rada? Odgovor je: Ne, ne proizvodimo. Naime, od 2010.-2017. hrvatski visoko-obrazovni sustav ,proizvodi“ oko 32. 000 diplomiranih studenata. Kao ,proxy“ varijablu njihove zapošljivosti uzeli smo broj visoko-obrazovanih nezaposlenih bez radnoga staža. Ta kategorija zadovoljavajuće interpretira zapošljivost onih koji imaju diplomu ali nemaju radno iskustvo, što su upravo diplomirani studenti prijavljeni na zavodima za zapošljavanje. Vidimo da taj broj varira s poslovnim ciklusom. „Zagrijavanjem“ krize 2012. godine taj se broj povećao s 6.908 na 10. 222, čime je udjel nezaposlenih među diplomiranima povećan od 21\% na $28 \%$. „Rasplamsavanjem“ krize 2014. zapošljivost je dodatno smanjena: bez posla je $32 \%$ odnosno $1 / 3$ tercijarno obrazovanih. No „splašnjavanjem“ krize odnosno gospodarskim oporavkom u 2017 samo je $15 \%$ odnosno malo više od 1/6 tercijarno obrazovanih bez posla godinu dana nakon diplome (Tablica 9).

Tablica 9. Dinamika odnosa diplomiranih i nezaposlenih s tercijarnim obrazovanjem

\begin{tabular}{|c|c|c|c|}
\hline Godina & $\begin{array}{c}\text { Diplomirani } \\
\text { studenti }\end{array}$ & $\begin{array}{c}\text { Tercijarno } \\
\text { obrazovani } \\
\text { nezaposleni }\end{array}$ & $\begin{array}{c}\text { Odnos nezaposlenih tercijarno obrazovanih } \\
\text { bez radnoga staža i diplomiranih studenata }\end{array}$ \\
\hline 1990. & 10.338 & 6.789 & $66 \%$ \\
\hline 2000. & 13.510 & 7.528 & $56 \%$ \\
\hline 2010. & 32.278 & 6.908 & $21 \%$ \\
\hline 2012. & 36.964 & 10.222 & $28 \%$ \\
\hline 2014. & 33.741 & 10.755 & $32 \%$ \\
\hline 2016 & 32.895 & 7.695 & $23 \%$ \\
\hline 2017 & 32.728 & 5.038 & $15 \%$ \\
\hline
\end{tabular}

Izvor:Priopćenja DZS-a, Hrvatski zavod za zapošljavanje

Drugo je pitanje proizvodi li visoko obrazovanje nezaposlenost umjesto rasta? I na ovo je pitanje odgovor : Ne, ne proizvodi. U razdoblju krize 2010. - 2012. dolazi do krupnih dinamičkih i strukturnih promjena. Broj nezaposlenih tercijarno obrazovanih porastao je za oko $50 \%$. Istodobno je ukupan broj nezaposlenih porastao za gotovo 18 $\%$. To je rezultiralo povećanjem udjela tercijarno obrazovanih nezaposlenih u ukupnoj nezaposlenosti na $2,9 \%$, da bi 2014. dostigao 3,2 \%. No i ovdje ,splašnjavanjem“ krize i umjerenim oporavkom taj je odnos u 2017. pao na 2,6 \% (Tablica 10.). 
Tablica 10. Obrazovanost i nezaposlenost

\begin{tabular}{|c|l|l|c|}
\hline Godina & $\begin{array}{l}\text { Tercijarno obrazovani } \\
\text { nezaposleni }\end{array}$ & $\begin{array}{l}\text { Ukupno } \\
\text { nezaposleni }\end{array}$ & $\begin{array}{l}\text { \% udjel } \\
\text { Kol. 2/3 }\end{array}$ \\
\hline 1 & \multicolumn{1}{|c|}{2} & 3 & 4 \\
\hline 1990. & 6.789 & 160.617 & 4,2 \\
\hline 2000. & 7.528 & 357.872 & 2,1 \\
\hline 2010. & 6.908 & 302.425 & 2,3 \\
\hline 2012. & 10.222 & 350.000 & 2,9 \\
\hline 2014. & 10.755 & 328.187 & 3,2 \\
\hline 2016 & 7.695 & 241.860 & 3,1 \\
\hline 2017 & 5.038 & 193.967 & 2,6 \\
\hline
\end{tabular}

Izvor: Priopćenja DZS-a, Hrvatski zavod za zapošljavanje

Statistički dokumentiran odgovor na oba pitanja upućuje na tzv. cikličku nezaposlenost tercijarno obrazovanih prouzročenu stanjem poslovnoga ciklusa. Istodobno odgovor ne upućuje na tzv. strukturnu nezaposlenost tercijarno obrazovanih koja bi bila prouzročena neodgovarajućom strukturom ponude tercijarno obrazovanih struka i kvalifikacija.

Cjeloživotno obrazovanje. Pri tome sve te bitne elemente valja sagledati u novoj perspektivi cjeloživotnog obrazovanja. Sadašnje formalno visoko obrazovanje koje završava „preddiplomskom“ kvalifikacijom prvostupnika, „diplomskim“ zvanjem magistra struke i poslijediplomskom titulom doktora znanosti, valja shvaćati kao početne „karike“ u cjeloživotnom obrazovanju. Ubrzani tehnološki napredak i kontinuirane inovacije znatno -,,skraćuju“- ,valjanost trajanja“ pojedinoga zanimanja odnosno struke. Stoga valja uspostavljati sustav kojim će se postupno širiti obveza (za sada samo reguliranih profesija) obnavljanja, nakon određenog vremena, znanja i profesionalne licence. Valja pronaći odgovarajuće oblike obveze obnavljanja licence za obavljanje stručnih poslova i na ostale struke te ih povezati s cjeloživotnim obrazovanjem i potrebom tercijarno obrazovanih zaposlenika da u određenim vremenskim intervalima pohađaju kraće programe obnove znanja i (re)kvalifikacije u sustavu visokoga obrazovanja. Cjeloživotno obrazovanje treba omogućiti i vertikalnu mobilnost odnosno stjecanje novih znanja i kvalifikacija zaposlenih sa srednjom ili nižom spremom.

Metode učenja i mobilnost. Izložena djelomična ocjena stanja sustava visokoga obrazovanja ponajprije upućuje na ključne probleme u sustavu koje valja adresirati da bi se ostvarili stvarno potrebni pomaci. To je dakako pitanje što treba učiti, kako u pojedinom kurikulumu inovirati, modificirati, preoblikovati i/ili napuštati postojeća $i$ usvajati nova znanja? No jednako je važno pitanje kako učiti. I najsuvremeniji obrazovni sustavi poput američkoga suočeni su s velikim postotkom dugoga studiranja i napuštanja sveučilišta, osobito s nezadovoljavajućim napretkom u usvajanju znanja na kraju u odnosu na početak studiranja. Uočena je neefikasnost osobito klasičnih predavanja u prenošenju znanja američkim studentima, jer se studenti netom nakon predavanja sjećaju 
manje od $50 \%$ informacija iznesenih tijekom predavanja, a $20 \%$ im ostaje u sjećanju tjedan dana poslije (Bok, 2013). Polazeći od saznanja kako predavanjima mogu efikasno prenositi informacije, ali ne i efikasno promicati (kritičko) razmišljanje i sposobnost rješavanja problemskih zadataka, istraživači pedagoških tehnika upućuju na kombinaciju predavanja s grupnim i individualnim rješavanjem problemskih zadataka, stimuliranjem kritičkoga mišljenja u manjim debatnim skupinama, interaktivnim zajedničkim učenjem i slično (Tablica 11).

Tablica 11. Strukturne promjene u metodama učenja na američkim sveučilištima od 1991. -2011. (\% institucija u kojima se koriste pojedini oblici učenja)

\begin{tabular}{|l|c|c|}
\hline & $1991 .-1993$. & $2010 .-2011$. \\
\hline Ekstenzivna predavanja & 54,2 & 47,4 \\
\hline Diskusije u predavaonicama & 69,4 & 80,7 \\
\hline Kooperativno/grupno učenje & 31,7 & 53,7 \\
\hline Učenje u praksi/studijska putovanja & 19,8 & 23,4 \\
\hline Grupni projekti & 21,6 & 30,4 \\
\hline Višekratna izrada pisanih radnih materijala & 14,4 & 21,7 \\
\hline
\end{tabular}

Izvor: Bok (2013:215)

Suvremena nastava i potreba njenog paralelnog izvođenja na materinskom i svjetskim (engleskom) jezicima temeljna je pretpostavka internacionalizacije hrvatskoga sustava visokoga obrazovanja. To se osobito odnosi na dolaznu mobilnost studenata koji žele steći diplomu. Takvih je studenata u Velikoj Britaniji, na Cipru i u Austriji više od $15 \%$, a Hrvatska je na samom začelju - samo 0,6\%. Povoljnija je situacija s odlaznom mobilnosti studenata koji stječu diplomu izvan matične zemlje. Hrvatska se s odlaznom mobilnošću od 4,4 \% nalazi na 16. mjestu od 28 članica EU (European Commision, 2018c).

\section{OSNOVNA PITANJA I CILJEVI INSTITUCIONALNE REFORME}

Osnovni ciljevi reforme sustava postulirani u zakonskim rješenjima jesu unapređenje individualne kvalitete znanstvenoga i nastavničkoga rada, unapređenje kvalitete nastavnih i istraživačkih programa i njihove povezanosti s praksom, unapređenje kvalitete nastavno-znanstvenih institucija te unapređenje učinkovitosti kvalitete upravljanja sustavom znanosti i visokoga obrazovanja.

\subsection{Unapređenje kvalitete znanstvenoga i nastavnoga rada}

Nastavnik koji je sposoban prenositi znanje i osobito poučavati kako učiti i istraživati ključni je provoditelj reforme i zakona o visokom obrazovanju. Zato stvaranje institucionalno-financijskoga okvira za kvalitetnoga nastavnika i istraživača, među ostalim, čine sljedeći ciljevi: 
- najmanje jedan objavljeni znanstveni rad godišnje u visoko rangiranom časopisu (prema znanstvenom području/polju) s pokrivenim troškom objave u otvorenom pristupu,

- za one suradnike koji nisu studirali nastavničke struke odnosno stekli nastavničku izobrazbu organizacijski i financijski osigurati jedan semestar pedagoško-metodičkoga obrazovanja prije izbora u znanstveno-nastavno zvanje,

- težiti i financijski osigurati suradnju s gospodarstvom putem prakse u hrvatskim gospodarskim subjektima, znanstvenim centrima izvrsnosti, centrima kompetencije $\mathrm{i} / \mathrm{ili}$ znanstveno tehnologijskim parkovima, institucijama $\mathrm{i} / \mathrm{ili}$ stručnim tijelima, ugrađenu u nastavno-istraživačko opterećenje prema kolektivnom ugovoru i odgovarajuće povećanje broja nastavnika-istraživača i suradnika,

- ugovoriti i financijski osigurati najmanje jedan semestar usavršavanja na uglednim inozemnim znanstvenim institucijama prema rangu/mjerilima $u$ svakom znanstvenom području, ugrađenom u nastavno-istraživačko opterećenje prema kolektivnom ugovoru i odgovarajuće povećanje broja nastavnikaistraživača i suradnika,

- osigurati sredstva za osposobljavanje nastavnika za digitalizirane metode poučavanja, nastavnoga materijala i interaktivnu virtualnu i klasičnu komunikaciju sa studentima,

- načelno tretirati sadašnje razine nastavničkih plaća kao početni fiksni dio te osigurati dodatnih $25-30 \%$ za varijabilni dio plaće za izvrsnost za znanstvene i/ili nastavne rezultate, narečene ciljeve prilagoditi/povećati za znanstvena radna mjesta bez nastavnih obveza u javnim znanstvenim institutima.

Izbor u znanstveno nastavna-zvanja. Trenutačno je u hrvatskom sustavu visokoga obrazovanja zaposleno ukupno 7579 nastavnika (2598 redovitih profesora i redovitih u trajnom zvanju, 1836 izvanrednih profesora, 3245 docenata) (DZS, 2016). Uz stručna povjerenstva njihov izbor u znanstvena zvanja provode 22 znanstvena i jedan umjetnički matični odbor s ukupno oko 250 članova redovitih profesora. Matični odbori godišnje provode ukupno oko 1000-1200 izbora u sva znanstvena zvanja (NVZVOTR, 2016/2017). To znači da član matičnoga odbora kao izvjestitelj godišnje prosječno analizira 4-5 izbora u znanstvena zvanja. Relativno mala hrvatska znanstveno-nastavna zajednica treba stalno podizati kvalitetu i poticati znanstveno napredovanje podižući kriterije međunarodno vidljive i nacionalno relevantne znanstvene izvrsnosti. Zato se zakonskim rješenjem, sukladno SOZT, predlaže razrada istorazinskoga (peer-review) sustava. Kako bi se osigurala objektivnost i kompenzirala bitno različita veličina znanstveno-nastavne zajednice na pojedinim hrvatskim sveučilištima, uspostavlja se dvostruki istorazinski (peer-review) sustav. U prvom krugu njega čine stručna povjerenstva, koja uključuju i mogućnost inozemnih vanjskih članova. U drugom krugu to su matični odbori. Kontinuirano podizanje kriterija znanstvene izvrsnosti osigurava se periodičnim podizanjem uvjeta za izbor u pojedina zvanja, na temelju međunarodne 
vidljivosti znanstvenoga napredovanja i inovativnosti, u odgovarajućem pravilniku, koji treba dodatno vrednovati međunarodno iskustvo i sudjelovanje u kompetitivnim projektima.

Transparentnost i učinkovitost. Među temeljna pitanja svakako spada i prijevremeni izbor u zvanja, kao i izravni izbor u znanstvena zvanja viša od znanstvenoga suradnika za osobe koje dolaze iz inozemstva. Glede postupka izbora, jasno se propisuje da sastavnice i sveučilišta provode dio postupka za koji su ovlašteni te daju mišljenje i prijedlog, a konačan izbor provodi odgovarajući matični odbor. Precizirani su i skraćeni rokovi, kao i posljedice za njihovo prekoračenje. Transparentno i precizno propisani su postupci oduzimanja zvanja odnosno potvrde umjetničke komponente glede povreda etičkih kodeksa.

Pojednostavljen je način izbora na znanstveno radno mjesto. Ponajprije, više se ne traži objava natječaja u dnevnom tisku da bi se izbjegli nepotrebni troškovi. Zatim, uvodi se obveza svih znanstvenih organizacija da donesu opći akt kojim će propisati kriterije za izbor između više pristupnika. Ti su kriteriji iznimno važni jer skraćuju postupak u slučaju da se na natječaj javi osoba koja nema proveden izbor u znanstveno zvanje s obzirom na to da će se postupak izbora takve osobe u zvanje provesti isključivo ako je najbolji kandidat. Tim rješenjima potiče se i dolazak odnosno odabir novih znanstvenika iz druge institucije, gospodarstva i osobito iz hrvatske dijaspore. Dodatno, kao prednost za izbor uvodi se doktorsko ili poslijedoktorsko usavršavanje od najmanje šest mjeseci u inozemstvu. Uvodi se pravna zaštita protiv odluke o izboru pristupnika na znanstveno radno mjesto pred nadležnim sudom za radne sporove. Detaljnije se uređuje i prijevremeno napredovanje (izbor na više znanstveno radno mjesto nakon tri godine). Prilikom sklapanja ugovora o radu propisuje se obveza izbora na više radno mjesto $\mathrm{s}$ mogućnošću jednoga reizbora. Ako se i nakon reizbora osoba ne izabere na više radno mjesto, prestaje joj ugovor o radu ili ako u postupku reizbora znanstveno vijeće javnog znanstvenog instituta ne prihvati pozitivno izvješće stručnoga povjerenstva ili prihvati negativno izvješće o radu. Sukladno općim trendovima, rok za odlazak u mirovinu pomiče se na 67 godina, odnosno znanstveniku u javnom znanstvenom institutu istekom kalendarske godine u kojoj je navršio 67 godina života prestaje ugovor o radu zbog odlaska u mirovinu. Od toga pravila postoje dvije iznimke: ako za znanstvenikom postoji potreba, što utvrđuje ravnatelj, i pristupnik zadovoljava kriterije izvrsnosti, što utvrđuje Vijeće javnih znanstvenih instituta, uz pribavljeno mišljenje znanstvenoga vijeća javnoga znanstvenoga instituta. Treba istaknuti da mogućnost produženja na teret državnoga proračuna postoji samo za osobe u najvišem zvanju i na maksimalno tri godine. Druga iznimka odnosi se na situaciju ako su sredstva za plaću osigurana iz namjenskih sredstava za znanstvene ili stručne projekte ili iz vlastitih sredstava.

U sustavu visokoga obrazovanja uvele bi se slične promjene glede sustava napredovanja i produženja radnog odnosa, kao i u sustavu znanosti. Nacrtom se predlažu slična rješenja kao i za osobe u znanstvenim organizacijama. Ponajprije, uvodi se kao pravilo da je pri izboru u znanstveno-nastavno zvanje docenta prednost pri izboru doktorsko ili poslijedoktorsko usavršavanje od najmanje šest mjeseci na drugoj instituciji. Ostaje se na petogodišnjim razdobljima koja osoba mora provesti u nekom znanstvenonastavnom zvanju odnosno radnome mjestu, ali se preciznije propisuje kada se može 
provesti prijevremeni izbor. Posebno se propisuju uvjeti za izbor u umjetničko-nastavna zvanja i odgovarajuća radna mjesta. Kao i za znanstvene organizacije, briše se obveza objave javnoga natječaja u dnevnom tisku i propisuje se jasno tko provodi izbore $\mathrm{u}$ znanstveno-nastavna i umjetničko-nastavna zvanja i odgovarajuća radna mjesta: sveučilište kod institucionalno integriranih sveučilišta, a sastavnica sveučilišta kod funkcionalno integriranih sveučilišta. Odluku o raspisivanju javnoga natječaja donosi sveučilište kod institucionalno integriranih sveučilišta, odnosno sastavnica sveučilišta kod sveučilišta koja su funkcionalno integrirana, uz prethodnu suglasnost sveučilišta, u skladu sa statutom sveučilišta i statutom sastavnice. Uvodi se obveza donošenja kriterija za izbor između više kandidata, a izbor u znanstvena zvanja provodio bi se u postupku izbora u znanstveno-nastavna i umjetničko-nastavna zvanja te odgovarajuća radna mjesta samo ako bi pristupnik koji nema proveden taj izbor bio najbolji kandidat prema kriterijima koje bi odredilo visoko učilište. Svaki zaposlenik izabran na znanstvenonastavno radno mjesto ima pravo na jedan reizbor na isto znanstveno-nastavno radno mjesto - odnosno može ukupno provesti najviše deset godina u istom nastavnoznanstvenom zvanju i radnome mjestu, osim u zvanju i na rednom mjestu redovitoga profesora u trajnom zvanju, za koje nema ponovnog izbora odnosno reizbora. Ako se zaposlenik ne javi na javni natječaj za napredovanje, a ne bude reizabran u isto zvanje ili ne bude izabran zbog neispunjenja uvjeta, pokrenut će se postupak otkaza ugovora uvjetovan skrivljenim ponašanjem radnika, bez obveze da mu se ponudi drugo odgovarajuće radno mjesto.

Predloženom se reformom uklanja jedan od najvećih problema sustava visokog obrazovanja, a to je nepostojanje minimalnih uvjeta za reizbor. Predviđa se da ih donosi Rektorski zbor, koji bi određivao oblik izvješća o reizboru, kao i minimalne uvjete radnih obveza zaposlenika.

Kao i kod znanstvenih organizacija, dob za odlazak u mirovinu pomiče se na 67 godina, uz istovjetne iznimke kao i za znanstvena - ako su sredstva za plaću osigurana iz namjenskih sredstava za znanstvene ili stručne projekte, ili iz vlastitih sredstava, odnosno ako postoji potreba, koju utvrđuje čelnik, i kandidat zadovoljava kriterije izvrsnosti koje donosi Rektorski zbor, što utvrđuje stručno vijeće uz pribavljeno mišljenje senata odnosno njegova odgovarajućega područnoga vijeća.

Za suradnike, o kojima ovisi budućnost sveučilišta, posebno se preciziraju uvjeti za izbor. Tako se predviđa da bi se osobito uzimalo u obzir sljedeće: za asistenta - prosjek ocjena, duljina studija, ostvareni posebni uspjesi na studiju (dekanova nagrada, rektorova nagrada i sl.), objavljeni znanstveni i stručni radovi, a za poslijedoktoranda - prosjek ocjena na poslijediplomskom studiju, duljina studija, broj objavljenih znanstvenih i stručnih radova, sudjelovanje na znanstvenim projektima. Dodatno, izbor mora biti obrazložen tako da se utvrdi zadovoljenje navedenih kriterija. Predviđeno je sklapanje ugovora na određeno vrijeme za prvo, suradničko (asistentsko/(poslijedoktorandsko) radno mjesto do maksimalno šest godina. To efektivno omogućuje uspostavu „ubrzanih“ (tenure track) radnih mjesta. Znanstvena će organizacija u tom vremenu moći realno procijeniti istraživačko-nastavni potencijal kandidata: je li kvalitetnim istraživanjem uspješno obranio disertaciju, surađuje li dovoljno kvalitetno s kolegama u projektnim skupinama i nastavi, objavljuje li kvalitetne znanstvene radove odnosno ostvaruje li 
dovoljnu znanstveno-nastavnu dodanu vrijednost za izbor u znanstveno - nastavno zvanje - i sklapanje ugovora na neodređeno vrijeme. Istodobno, omogućuje se već nakon tri godine i stjecanja doktorata stalno radno mjesto poslijedoktoranda odnosno docenta. Tako je otvoren put za privlačenje mladih darovitih znanstvenika.

\subsection{Unapređenje kvalitete i internacionalizacija nastavno-istraživačkih programa}

Programi sveučilišnoga visokoga obrazovanja, kao drugi potporni stup institucionalizacije reformi, zahtijevaju rastući napor u unapređenju svoje kvalitete od preddiplomskih preko diplomskih do poslijediplomskih (doktorskih) studija, što uključuje višejezičnost svih razina studija.

Hrvatsko preddiplomsko (nekadašnji VSS) visoko obrazovanje načelno i u prosjeku daje solidnu naobrazbu. Tome u prilog ide činjenica kako se hrvatski sveučilištarci bez većih problema upisuju na magistarske (masters) i doktorske programe na uglednim svjetskim sveučilištima. Istodobno, učestale su primjedbe hrvatskih poslodavaca kako završeni studenti ne posjeduju dovoljno u praksi primjenjivih znanja i vještina. Značajnije reformsko unapređenje čeka diplomsko i poslijediplomsko obrazovanje. Diplomski studiji trebaju naprednije teorijsko metodološko-analitičko profiliranje. Uspješno ovladavanje kompleksnijim spoznajama, teorijski složenijim istraživačkim metodama i empirijskim modelima na diplomskom studiju preduvjeti su ulaska u pun istraživački pogon doktorskih studija. Kreiranje inovativnih istraživačkih obrazaca i iskoraci u znanstvenim spoznajama koji postupno i sitnim pomacima mijenjaju društveno i proizvodno okruženje i/ili podržavaju značajnije mijenjanje ustaljene paradigme, zadaće su poslijediplomskih (doktorskih) studija. Rast kvalitete nalaže izlazak podobnih hrvatskih programa izvođenih i na svjetskim jezicima na međunarodno visokoobrazovno tržište. Sposobnost privlačenja stranih studenata prema konkurentskim uvjetima može biti jedan od prihvatljivih indikatora kvalitete. Paralelno izvođenje programa na hrvatskom i svjetskom jeziku istodobno je i dobar put razvoja moderne hrvatske znanstvene terminologije i doprinos razvoju nacionalnog identiteta (Družić, 2019).

Ciljevi predložene zakonske reforme kojima se potiče napredak kvalitete i internacionalizacija nastavno-istraživačkih programa su među ostalim:

- uvođenje obveze minimalno jednomjesečne prakse studenata tijekom svake godine preddiplomskoga/diplomskoga studiranja, na terenskom radu i/ili u gospodarskim subjektima i/ili javnim službama i/ili civilnim udrugama i/ili stručnim udruženjima, sindikatima i drugim institucijama i službama, kao integriranoga dijela ECTS sustava, te uz pokrivene troškove mentora prakse,

- $\quad$ studentsku stručnu praksu ugovaraju fakulteti i/ili sveučilišta, koristeći svoje alumni udruge, sektorske interesne mreže i druge mogućnosti stvaranja mentorske mreže stručne prakse,

- preddiplomske studije dograditi temeljnim znanjima prirodno-tehničkih i društveno humanističkih znanosti te stimuliranjem kritičkoga problemskoga promišljanja kao intelektualnom infrastrukturom koja širinom obrazovanja 
omogućuje brzu prilagodbu promjeni kvalifikacija i novim strukama tijekom radnoga vijeka,

- diplomske studije temeljiti na produbljenim teorijskim znanjima i složenijim analitičkim postupcima, s naglaskom na razvijanje sposobnosti promišljanja i identificiranja kompleksnih stručnih problema i društvenih izazova odnosno kreiranja istraživačko-analitičke osnove njihova rješavanja u novim razvojnim okruženjima,

- poslijediplomske (doktorske) studije, temeljem svladane teorijsko-metodološke podloge na diplomskim studijima, dominantno koncipirati kao konkretno istraživanje i što više povezati s nacionalnim, kompetitivnim i međunarodnim znanstveno-istraživačkim projektima, te s primijenjenim istraživanjima od interesa za hrvatsko gospodarstvo i poduzetnike i/ili hrvatsko društvo, kulturu i znanost,

- omogućiti protočnost nastavnika između razina tercijarnoga obrazovanja, koncentraciju nastavnih obveza nastavnika voditelja istraživačkih projekata na doktorskim studijima te ostalih nastavnika-istraživača na onim obrazovnim/istraživačkim programima koji optimiziraju njihovu ekspertizu, te oblikovati odgovarajući sustav cjelovitoga vrednovanja nastavnoga i/ili znanstvenoga doprinosa nastavnika i/ili istraživača,

- programski i financijski poticati integriranje nacionalnih i međunarodnih istraživačkih projekata javnih znanstvenih instituta $\mathrm{u}$ poslijediplomske (doktorske) programe u svim znanstvenim područjima,

- postupno širiti obvezu (reguliranih profesija) obnavljanja, nakon određenoga vremena, profesionalne licence za obavljanje stručnih poslova i na ostale struke te ju povezati s cjeloživotnim obrazovanjem i potrebom tercijarno obrazovanih i zaposlenika da kontinuirano obnavljaju znanja kraćim programima u sustavu visokoga obrazovanja,

- $\quad$ izvedba svih nastavnih programa, nastavni kapaciteti i znanstvena infrastruktura (prostori i oprema) nužni za izvedbu studijskih programa određenoga visokoga učilišta moraju se svakih 5-7 godina podvrgnuti istorazinskoj međunarodnoj evaluaciji.

Zakonsko uređenje poticanja kvalitete nastavno-istraživačkih programa kao krucijalno pitanje razvoja sustava uređuje se ugradbom odredbi o osiguranju kvalitete u taj temeljni zakon umjesto posebnoga (izvedenoga) zakona. Time se postiže bitno koherentniji zakonodavni okvir koji bi regulirao sustav znanosti i visokoga obrazovanja tako da je međunarodno usporedivo ocjenjivanje kvalitete. To je jedna od bitnih novina kojom se unapređuje kvaliteta sustava. $U$ tu svrhu uređuje se unutarnji i vanjski sustav osiguravanja i unapređivanja kvalitete, inicijalna akreditacija i uvjeti za akreditaciju, reakreditaciju, vanjsko vrednovanje unutarnjega sustava osiguravanja i unapređivanja kvalitete i tematsko vrednovanje. Posebna se pozornost posvećuje osiguranju stručne nezavisnosti Agencije za znanost i visoko obrazovanje. Prijedlogom reformskog zakonskog rješenja jača stručna nezavisnost Akreditacijskoga savjeta AZVO-a, poglavito 
transparentnim postupkom akreditacije i imenovanjima međunarodnih stručnih povjerenstava za ocjenu kvalitete nastavno-istraživačkih programa i organizacija.

Ugradba odredbi o osiguranju i unapređenju kvalitete u Zakon o znanstvenoj djelatnosti i visokom obrazovanju ima bitno značenje za ukupnu međunarodno usporedivu kvalitetu sustava jer:

- na temelju dosadašnjih iskustava unapređuje i razvija sustav osiguravanja kvalitete,

- $\quad$ podiže kriterije i uvjete osnivanja i programskoga funkcioniranja institucija visokoga obrazovanja,

- određuje dionike sustava osiguravanja i unapređivanja kvalitete visokoga obrazovanja i znanstvene djelatnosti, njihove međusobne odnose i odgovornosti.

\subsection{Unapređenje kvalitete znanstveno-obrazovnih institucija - visokih učilišta i javnih znanstvenih instituta}

Hrvatski fakulteti i sveučilišta, kao autonomni organizacijski oblici, povezuju u cjelovite studije nastavnike-istraživače $s$ jedne i obrazovne programe te istraživačke projekte s druge strane. Silina tehnološkoga napretka, novih tehnologija i inovacija imaju izravnu posljedicu postupnog nestanka brojnih današnjih struka i zanimanja povezanih s industrijskim i uslužnim fizičkim radom te nastanak novih. To traži fakultete i sveučilišta koji nude nova zanimanja, struke i kvalifikacije temeljene na inter/multi/transdisciplinarnosti, što pretpostavlja i elastičnost i otvorenost unutarnjega ustroja sustava visokoga obrazovanja. Veleučilišta i visoke škole, osiguravajući primijenjena stručna znanja i kvalifikacije, bitan su čimbenik ubrzanoga transfera i primjene inovacija i novih tehnologija u društvenu i gospodarsku praksu.

Javni znanstveni instituti kao specifičan oblik organizacije koji povezuje istraživače i istraživačke projekte imaju gospodarstvo odnosno društvenu praksu i visoko obrazovanje (osobito doktorske studije) kao dva podjednako važna kraka svoje misije.

Unapređenje kvalitete kojim se visoka učilišta osposobljavaju ne samo za preuzimanje odgovornosti za znanstveno-stručnu podlogu ukupnoga društvenoga razvoja nego i za vlastitu kvalitetu definira se, među ostalim, sljedećim ciljevima;

- uvesti i u skladu s mjerama SOZT-a osigurati potrebna sredstva za mentorsku nastavu (povećani broj nastavnika) s manjim studijskim grupama u STEM i DH područjima umjesto predavačko/seminarskoga sustava,

- poticati međunarodnu konkurentnost uvođenjem višejezične nastave na hrvatskom i svjetskim jezicima važnima za pojedine struke. Internacionalizacijom težiti $\mathrm{k} 10-15 \%$ stranih studenata na hrvatskim sveučilištima, uz njihovo plaćanje realne cijene studijskoga programa,

- opremiti laboratorije i kabinete/učionice kapitalnom opremom, digitaliziranim otvorenim pristupom rezultatima svjetskih znanstvenih istraživanja, repozitorijima literature i mrežama velikih baza podataka, koristeći se nacionalnim i sredstvima europskih kohezijskih fondova,

- odlaznu mobilnost nastavnika i studenata dodatno stimulirati u STEM području i hvatanju istraživačko-tehnološkoga priključka sa suvremenim razvitkom. 
Dolaznu mobilnost dodatno stimulirati u DH području, osiguravajući međunarodnu vidljivost hrvatskih nacionalnih društvenih, povijesnih, arheoloških, kulturnih, umjetničkih i drugih specifičnih doprinosa međunarodnoj zajednici,

- digitalizirati nastavni proces i umreživati se sa svjetski rangiranim sveučilištima i institutima relevantnima za pojedine struke, uz osigurana sredstva prema mjerama SOZT-a,

- financijski poticati istraživačke ideje i projekte mladih istraživača,

- stručno i financijski podupirati objavljivanje u vrhunskim publikacijama otvorenoga pristupa za pojedine struke,

- poticati bilingvalna izdanja znanstvenih publikacija, na hrvatskom i stranom jeziku važnom za struku,

- utemeljiti sustav poticanja uvrštavanja i indeksiranja hrvatskih znanstvenih časopisa u svjetske citatne baze,

- obnoviti i razviti sustav uključivanja hrvatske znanstvene dijaspore u istraživačko-obrazovni proces,

- osigurati kraće studijske boravke svjetske istraživačke elite na hrvatskim sveučilištima i institutima,

- dodatno poticati uključivanje instituta u kvalitetne međunarodne kolaboracije i projekte kao bitnog elementa istraživačke misije,

- dodatno poticati uključivanje instituta $\mathrm{u}$ neposredne oblike suradnje $\mathrm{s}$ gospodarstvom uz poticanje programskoga uključivanja veleučilišta i visokih škola.

Ostvarenje narečenih ciljeva prijedloga zakona potiče se, prvo, otvaranjem međunarodnoj konkurenciji, što uključuje i istraživačku preobrazbu sveučilišta. Drugo, nudi se snažnije povezivanje i brže usklađivanje s potrebama hrvatskoga gospodarstva i društva:

- jačanje međunarodne konkurentnosti i mobilnosti stimulira se izvođenjem višejezičnih obrazovnih programa na hrvatskom i svjetskim jezicima (o čemu postoji višegodišnja dobra praksa na nekoliko fakulteta). Dva su temeljna cilja snažnijega iskoraka hrvatskih sveučilišta na međunarodnu razinu visokoga obrazovanja aktiviranjem centara za međunarodnu suradnju. Prvo, stvarna implementacija kriterija međunarodne izvrsnosti i rast mobilnosti. Drugo, više stranih studenata omogućuje kompenzaciju demografskog pada broja domaćih studenata, a time i rast vlastitih prihoda.

- $\quad$ istraživačka preobrazba sveučilišta: priljev inozemnih studenata povezan je i s rangiranjem, a rangiranje u bitnome i s kvalitetom publiciranih istraživanja. Sveučilišni znanstveno-inovacijski instituti, kao mogućnost a ne obveza, postaju ključ istraživačke preobrazbe i samostalni nositelji izvanproračunskih istraživačko-projektnih aktivnosti.

- povezivanje s hrvatskim gospodarstvom i društvom potiče se na dva načina. Prvo putem sveučilišnih centara za inovacije i transfer tehnologije koji 
promoviraju zajedničke projekte, štite intelektualno vlasništvo i stručno podupiru start-up projekte u visokim tehnologijama. Drugo putem centara za cjeloživotno obrazovanje koji programima prate razvoj pojedinih struka, organiziranju izvanredne studije i mentorsku stručnu praksu studenata.

Proračunska transparentnost. Kao jedan od bitnih preduvjeta sadržajne strukturne reforme svakako je proračunska transparentnost. To znači da Vlada i MZO putem riznice imaju kontrolu nad svim sredstvima koje država dodjeljuju sveučilištima. Sve ostalo, odnosno prihodi od aktivnosti sveučilišnih znanstvenih instituta i centara za međunarodnu suradnju, transfer tehnologije, cjeloživotno obrazovanje, kao i ostali izvori vlastitoga financiranja, u nadležnosti su upravljačkih sveučilišnih tijela.

\subsection{Ustroj i učinkovito upravljanje sustavom znanosti i visokoga obrazovanja}

Učinkovito upravljanje sustavom traži ustrojbenu konzistentnost. To, među ostalim, znači i „trodiobu ovlasti“" u sustavu između autonomnih sveučilišta, državnih strateških tijela (Nacionalno vijeće) i tijela državne uprave (MZO).

Sveučilište. Središte su reforme sveučilišta kao prvi dionik „trodiobe“, podrazumijevajući autonomiju uz odgovornost. Ona se ostvaruje dvjema polugama. Prva je savjet sveučilišta koji u novoj ulozi i proširenom sastavu osigurava javni interes. Ima, među ostalim, zadaću strateške procjene usklađenosti sveučilišnih programa s društvenim potrebama i dugoročnim potrebama tržišta rada. Ako je ona pozitivna tada AZVO nezavisnim i transparentnim postupkom međunarodnoga recenziranja utvrđuje je li program dovoljno kvalitetan za dopusnicu. Druga bitna poluga autonomije uz odgovornost neizostavno je senat sveučilišta pa prijedlog zakona razrađuje elemente programske, financijske i upravljačke autonomije sveučilišta što uključuje i kriterije demokratskoga biranja rektora i svih drugih dužnosnika.

Prijedlogom se razrađuju konkretna zakonska rješenja kojima se poboljšava učinkovitost sustava. Ponajprije, propisuje se da nije dopušteno osnivanje novih sveučilišta nastalih izdvajanjem iz postojećega sveučilišta bez dvotrećinske suglasnosti senata sveučilišta iz kojega bi se novo sveučilište izdvojilo. Propisuje se, za razliku od današnjeg uređenja, da sveučilište provodi sveučilišne studije u najmanje tri znanstvena i/ili umjetnička područja (danas je propisano dva). Detaljnije se propisuju posebne rektorove ovlasti, odnosno mogućnost da rektor obustavi odluke sastavnica ili suspendira čelnike sastavnica odnosno osobe koje pomažu čelniku i imenuje obnašatelja dužnosti, ali uz propisivanje mehanizama kojima se osigurava da rektor ne može zlorabiti svoje ovlasti. Propisuje se, nadalje, da je senat sastavljen primarno od dekana sastavnica kod funkcionalno integriranih sveučilišta, odnosno od čelnika organizacijskih jedinica kod institucionalno integriranih sveučilišta, osim kada je drukčije propisano statutom sveučilišta, kada se senat bira u skladu sa statutom sveučilišta. To znači da svako sveučilište može odlučiti kakav sastav senata želi. Proširuju se sastav i ovlasti sveučilišnoga savjeta koji bi imao do dvadeset članova koje imenuje senat (polovicu), osnivač, županija i HGK. Savjet bi sudjelovao u pokretanju studijskih programa i institucija (inicijalnoj akreditaciji) i u nastavku njihova rada (reakreditaciji) donoseći 
Stratešku procjenu o društvenoj relevantnosti i potrebama tržišta rada. Strateška procjena jest obvezno prethodno mišljenje koje senat ili njegova sastavnica trebaju pribaviti pri pokretanju novoga studijskoga programa (inicijalna akreditacija) i procjeni društvenih i potreba tržišta rada za nastavak rada institucije i obrazovanih programa. Dodatno, sveučilišni savjet može imati svoja radna tijela koja bi se osnivala sukladno potrebama sveučilišta (Družić, 2019.).

Kad je o sastavnicama riječ, predlažu se promjene glede mandata dekana koji bi bio ne kraći od tri, i ne duži od četiri godine, s mogućnošću jednoga ponavljanja, a uvodi se i mogućnost da dekanu u financijskom poslovanju pomaže financijski direktor visokoga učilišta.

Ministarstvo. Ministarstvo znanosti i obrazovanja (MZO) kao tijelo državne uprave drugi je dionik ,trodiobe“. Reformska uloga Ministarstva znanosti i obrazovanja podrazumijeva operativno upravljanje sustavom s brojnim stručnim zadaćama kao što su:

- donošenje upravnih i općih (podzakonskih) akata na prijedlog nacionalnih stručnih tijela kao što su Pravilnik o sadržaju dopusnice i Pravilnik o registru HKO-a,

- $\quad$ izdavanje javnih isprava kao što su dopusnice i licence na prijedlog nacionalnih stručnih tijela,

- $\quad$ analiza upisa i upisnih kvota, uspješnosti završetka studija i zapošljavanja

- vođenje evidencije nadarenih i nagrađivanih studenata,

- uspostava evidencije najuspješnijih znanstvenika i najbolje ocijenjenih nastavnika

- uspostava i vođenje godišnje evidencije praćenja karijera hrvatskih znanstvenika u inozemstvu koji su diplomirali/doktorirali na hrvatskim sveučilištima,

- $\quad$ vođenje registra krupne znanstvene opreme i znanstvene infrastrukture

- provedba postupaka natječaja nabave kapitalne opreme i znanstvene infrastrukture,

- upravljanje krupnim investicijskim projektima u sustavu znanosti i visokoga obrazovanja,

- upravni, inspekcijski i financijski nadzor i sklapanje bilateralnih/multilateralnih ugovora o međunarodnoj suradnji,

Nacionalno vijeće. Nacionalno vijeće za znanost, visoko obrazovanje i tehnološki razvoj (NVZVOTR) kao državno strateško tijelo treći je dionik ,trodiobe“. Ono svojim sastavom ojačanim autoritetom Hrvatskoga sabora čini kvalificirano „posredničko“ tijelo s primarnom zadaćom harmoniziranja upravno-administrativne i sveučilišno-autonomne vertikale sustava. To se među ostalim odnosi i na utvrđivanje strateških ciljeva obrazovnog procesa i znanstvenih istraživanja. Podrazumijeva i razradu kriterija raspodjele proračunskih sredstava namijenjenih financiranju znanosti i visokoga obrazovanja i - osobito kriterija prema kojima se sklapaju ugovori o programskom financiranju između sveučilišta i MZO-a.

Status krovnoga nacionalnoga tijela koje skrbi za razvitak i kvalitetu cjelokupne znanstvene djelatnosti i sustava znanosti, visokoga obrazovanja i tehnološkoga razvoja u 
RH traži razradu odgovarajućih zakonskih rješenja kojima Nacionalno vijeće, pored ostaloga:

- $\quad$ imenuje članove upravnih vijeća Hrvatske zaklade za znanost i Agencije za znanost i visoko obrazovanje,

- imenuje članove drugih tijela važnih za realizaciju strateških ciljeva kao što su savjet Hrvatskoga istraživačkoga prostora, Hrvatski strateški forum istraživačkih infrastruktura, Hrvatsko povjerenstvo za praćenje Bolonjskoga procesa, Vijeće za tehnologiju i inovacije. Ova tijela trebaju omogućiti sustavnu komunikaciju i praćenje rada odgovarajućih tijela Europskoga prostora visokoga obrazovanja (EHEA) i Europskoga istraživačkoga prostora (ERA),

- ima pojačane ovlasti glede proračuna u sustavu znanosti i njegova planiranja

Proširen je sastav NVZVOTR-a na 21 člana, kao i način imenovanja. Članove Nacionalnog vijeća i dalje bi imenovao Hrvatski sabor, ali prema sljedećem ključu: Rektorski zbor predlaže deset članova Nacionalnoga vijeća, od kojih pet mora biti sa Sveučilišta u Zagrebu, Vijeće znanstvenih instituta predlaže pet članova, od kojih dva moraju biti s instituta Ruđer Bošković, Vijeće veleučilišta i visokih škola predlaže tri člana, Hrvatska gospodarska komora predlaže jednog člana, Hrvatska udruga poslodavaca predlaže jednog člana i Hrvatska akademija znanosti i umjetnosti predlaže jednog člana (Staničić, 2019).

Ostala rješenja obuhvaćaju tijela i procedure bitne za učinkovito upravljanje sustavom znanosti i visokog obrazovanja.

Rektorski zbor: imao bi sljedeće ovlasti: propisivao bi, pravilnikom koji se objavljuje u „Narodnim novinama“, nužne uvjete za ocjenu nastavne i stručne djelatnosti $\mathrm{u}$ postupku izbora na znanstveno-nastavna, umjetničko-nastavna i nastavna zvanja odnosno radna mjesta, zatim, pravilnikom koji se objavljuje u „Narodnim novinama“, propisivao bi nužne uvjete za reizbor na znanstveno-nastavna, umjetničko-nastavna i nastavna zvanja odnosno radna mjesta, potom, propisivao bi pravilnikom koji se objavljuje u „Narodnim novinama“, kriterije za sklapanje ugovora na određeno vrijeme nakon navršavanja 67 godina života, predlagao bi članove područnih znanstvenih i umjetničkih vijeća i matičnih odbora, članove Savjeta za financiranje znanstvene djelatnosti i visokoga obrazovanja, razmatrao bi problematiku rada i razvoja sveučilišta i o tome donosio preporuke i mišljenja, davao bi prethodno mišljenje na propise koji se odnose na sustav visokoga obrazovanja te obavljao druge poslove koje mu povjere sveučilišta.

Vijeće javnih znanstvenih instituta. Novost je uvođenje novoga tijela u sustav znanosti - Vijeća javnih znanstvenih instituta, koji čine ravnatelji svih javnih znanstvenih instituta u Republici Hrvatskoj. To bi tijelo bilo pandan Rektorskome zboru i imalo bi sljedeće ovlasti: propisivalo bi, pravilnikom koji se objavljuje u „Narodnim novinama“, kriterije izvrsnosti za sklapanje ugovora o radu sa znanstvenicima u javnim znanstvenim institutima nakon 67 godina života uz prethodnu suglasnost Nacionalnog vijeća, pravilnikom koji se objavljuje u „Narodnim novinama“, propisivalo bi minimalne uvjete za reizbor na znanstveno radno mjesto, razmatralo bi problematiku rada i razvoja javnih znanstvenih instituta i o tome donosilo preporuke i mišljenja, odlučivalo bi o zadovoljenju 
kriterija izvrsnosti za sklapanje ugovora o radu sa znanstvenicima u javnim znanstvenim institutima nakon navršavanja 67 godina života te propisivalo uvjete za ravnatelje javnih znanstvenih instituta uz suglasnost Nacionalnoga vijeća.

Funkcionalno i institucionalno integrirana sveučilišta. U početnim odredbama Prijedloga definirana su dva tipa sveučilišta: funkcionalno integrirano sveučilište kao sveučilište koje je ustrojilo sastavnice s pravnom osobnošću i institucionalno integrirano sveučilište kao sveučilište koje nije ustrojilo sastavnice s pravnom osobnošću.

Etika u znanosti i visokom obrazovanju. Pojačana je obveza poštivanja etičkih postulata propisivanjem obveze donošenja etičkih kodeksa kojima se štiti znanstvena istina, istraživačka nepristranost, izvornost znanstvenog istraživanja i objave rezultata znanstvenoga rada, zaštita od svih oblika ugroze znanstvenoga poštenja, neovlaštenoga prisvajanja tuđega intelektualnoga vlasništva i rezultata istraživanja, a koji moraju biti usklađeni s etičkim kodeksom Odbora za etiku Hrvatskoga sabora.

Troškovna učinkovitost. Potiče se mogućnošću ustrojavanja zajedničkih službi kako bi se racionaliziralo poslovanje, napose računovodstvo, službe ljudskih potencijala i službe za javnu nabavu.

Kvalitetno financiranje. U tu svrhu Prijedlogom se definiraju vlastiti prihodi, primjerice ostvareni od školarina, istraživačkih, umjetničkih i stručnih projekata, elaborata, ekspertiza, nakladničke i drugih djelatnosti. Samo sredstva koja dolaze od osnivača, državnoga proračuna i proračuna županija, općina i gradova predstavljala bi dio proračunskih sredstava MZO-a i ulazila bi u državnu riznicu. Sredstva ostvarena na drugi način ne ulaze u proračunska sredstva ministarstva nadležnoga za visoko obrazovanje $i$ znanost odnosno u državni proračun i državnu riznicu. Nacionalno vijeće ima ključnu ulogu u planiranju i raspodjeli proračuna za sustav znanosti i visokoga obrazovanja pa se predlaže da ono utvrđuje kriterije za raspodjelu proračunskih sredstava, što uključuje i kriterije za sklapanje programskih ugovora na temelju prijedloga Savjeta za financiranje znanstvene djelatnosti i visokoga obrazovanja. Sredstva za razvoj sustava znanosti i visokoga obrazovanja, znanstvene, umjetničke i istraživačke projekte i programe, znanstvenu, umjetničku i istraživačku infrastrukturu i opremu, znanstveno izdavaštvo, znanstvene konferencije te znanstvene i znanstveno stručne udruge raspoređuje ministar na temelju javnoga poziva i na njemu temeljenoga prijedloga Nacionalnoga vijeća (Staničić, 2019.).

\section{ZAKLJUČNA OCJENA I IZVORI POTREBNIH SREDSTAVA}

Polazište je zakonskoga uređenja znanstvene djelatnosti i visokoga obrazovanja prilagodba hrvatskoga sustava novoj, u svjetskim razmjerima prepoznatoj vodećoj ulozi obrazovanja i znanstvenih istraživanja u ukupnom društvenom, gospodarskom, kulturnom i umjetničkom kao i osobnom razvoju.

Ubrzani razvoj novih tehnologija i inovativnih procesa rezultira promjenom cjelokupne tehnološke paradigme u kojoj je ljudski rad, pored prirodnih resursa i proizvodnog kapitala, bio tek jedan od triju proizvodnih faktora. U novim tehnološkim i organizacijskim obrascima, ljudski potencijali postaju (infrastrukturna) pretpostavka 
inovativnoga učinkovitoga korištenja ostalih dvaju faktora; prirodnih resursa i proizvodnoga kapitala.

Osobita se odgovornost znanosti i visokoga obrazovanja odnosi na adresiranje popratnih socijalnih izazova. Filozofski, estetski, kulturni i etički aspekti nove stvarnosti zahtijevaju institucionalna rješenja koja potiču ubrzan razvoj i sustava i kvalitete visokoga obrazovanja te intenziviranje $i$ podizanje međunarodne relevantnosti znanstvenih istraživanja i inovacijske aktivnosti. To je temeljni preduvjet hvatanja europskog razvojnog koraka i ugradbe hrvatske nacionalne prepoznatljivosti u evoluciju europskog civilizacijskog kruga.

Dva su stožerna subjekta koja, kao jedini stvaratelji znanstveno-obrazovne dodane vrijednosti, čine početak i kraj reformi. Prvi je stožerni subjekt student organski povezan sa svijetom rada, ohrabrivan u buđenju intelektualne radoznalosti i u punoj kritičkoj i kreativnoj slobodi. Interakcija studiranja/istraživanja i svijeta rada čini studiranje relevantnim, a društvenu praksu sposobnu odgovoriti socijalnim, tehnologijskim i drugim izazovima. Polazište je prvo maksimalna usklađenost ponude obrazovnih programa s identificiranim sposobnostima i sklonostima studenata, potom sa strateškim razvojnim interesima društva i države, i nakon toga s trenutačnim potrebama tržišta rada. Drugi je stožerni subjekt nastavnik/istraživač, sposoban prenositi znanje i osobito poučavati kako učiti i istraživati. On je ključan stvaran provoditelj reforme. Istinska realizacija propisanih ishoda učenja i stvarna kvaliteta istraživanja bit će onoliko životni koliko su sposobni i motivirani nastavnici/istraživači. Zato je nezaobilazan razlog za reformu stvaranje poticajnoga institucionalno-financijskoga okvira za kvalitetnoga nastavnika/istraživača prema međunarodno usporedivim kriterijima.

Kvaliteta znanstvenih istraživanja. Komparativnom analizom podataka iz statističkih publikacija EU bjelodano je zaostajanje RH u 2000-im, osobito nakon krize 2008. godine. Hrvatska se nalazi uglavnom između 25. i 27. mjesta od donedavnih 28 članica EU prema svim bitnim elementima znanstvene politike: znanstvenoj produktivnosti mjerenoj međunarodnom vidljivošću i citiranošću, broju istraživača u ekvivalentu punoga radnoga vremena (FTE), inovativnosti i broju patenata, broju i razvijenosti istraživačkih jedinica u gospodarskim subjektima, izdvajanjima poslovnoga sektora za istraživanje i razvoj, nacionalnim javnim/proračunskim izdvajanjima.

Europska strategija u području znanstvenih istraživanja i razvoja, upravljena na podizanje konkurentnosti istraživanja i razvoja, je povećanje izdvajanja za istraživanje $i$ razvoj (I\&R) zemalja članica na 3\% BDP-a. To podrazumijeva da se nakon 2020. udvostruči proračun EU za razvoj i istraživanje.

Europska komisija (EK) redovito (godišnje) ocjenjuje pripravljenost svake članice, pa tako i Hrvatske, da svojom politikama ostvaruje nacionalne ciljeve i doprinese rastu kvalitete i konkurentnosti znanstvenih istraživanja i inovativnosti Europske unije.

Europska je komisija ustanovila kako zaostajanje hrvatskoga sustava I\&R za ostalim članicama EU uvelike rezultat oskudnih javnih ulaganja, a potom i fragmentiranosti hrvatskih institucija visokoga obrazovanja, nedostatka poticaja za karijere istraživača i zanemarivanja relevantnosti internacionalizacije hrvatske znanstvene i inovacijske arene. Ocjenu, koja na prvo mjesto kao uzrok zaostajanja, stavlja javno financiranje, Europska komisija temelji na konkretnim pokazateljima. 
Hrvatska se s 0,79\% izdataka za I\&R u 2014. nalazi na 25. mjestu među 28 članica EU. Hrvatska se s 1,03\% izdataka za I\&R u 2004. nalazila na 16. mjestu među 28 članica EU.

Hrvatska je jedina članica EU koja je u desetljeću 2004. - 2014. smanjila ukupan iznos izdvajanja za I\&R od 345 na 340 milijuna $€$. Raščlanjujući efikasnost hrvatskih javnih/proračunskih izdataka, EK ističe kako su hrvatski rezultati u efikasnosti korištenja kompatibilni s rezultatima peer grupe zemalja (Poljska, Latvija, Slovačka) dakle sa zemljama s usporedivim ulaganjima u znanost u odnosu na BDP. Međutim, u usporedbi s EU prosjekom, Hrvatska ima vrlo slabe rezultate u kvaliteti znanstvenoga outputa jer među $10 \%$ svjetski najcitiranijih publikacija kao postotkom ukupnih znanstvenih publikacija ima 4,1\% u odnosu na EU prosjek od 11,1\%. Spoznaja kako je hrvatska znanstveno-istraživačka produkcija ,u skladu“ s ,tranzicijskim“ susjedima u srednjoj Europi, ali i kako kvalitetom zaostaje za EU prosjekom važna je za početnu ocjenu stanja kao i sugestija Europske komisije kako bez promjene u strukturi proračunskih izdataka u korist prometa i znanosti i obrazovanja, Hrvatska ne može ostvariti održivi rast.

Gotovo konstantna hrvatska vrhunska znanstvena produkcija od 4\% tijekom ovog razdoblja rezultira posebno zabrinjavajućom činjenicom po kojoj je hrvatska znanost „zarobljena“ u tzv. niskoj ravnoteži odnosno ravnoteži pri relativno visokom stupnju „nezaposlenosti“ znanstvenih resursa.

Zato je efikasnosti znanstveno-istraživačke djelatnosti Hrvatske kao male zemlje potrebno posvetiti dodatnu pozornost. Naime, kako javno izdvajanje znanstvena istraživanja obuhvaća sva znanstvena područja, to stavlja u različiti položaj veće u odnosu na manje zemlje, odnosno „veće“ u odnosu na „manje“ jezike, u pojedinim znanstvenim područjima.

U pojedinim znanstvenim područjima manje su zemlje odnosno njihove publikacije na materinskom jeziku u startu hendikepirane glede mogućnosti (konkurentnosti) publiciranja u svjetskim visoko citiranim časopisima. To se osobito odnosi na društvene i humanističke znanosti. Tako primjerice radovi koji se bave hrvatskim povijesnim, ekonomskim, pravnim ili sociološkim temama bitnima za hrvatski društveni, kulturni i gospodarski razvoj i nacionalni identitet i koji su pri tome objavljeni na hrvatskome jeziku, ne moraju biti zanimljivi široj svjetskoj znanstvenoj javnosti. Stoga je i mogućnost njihove objave u svjetskim časopisima u startu niža. No to se može odnositi i na prirodoslovno i/ili biotehničko područje kada istražuju pojave ili procese povezane sa specifičnostima hrvatskoga razvoja. Za zemlju koja je kao Hrvatska relativno nedavno stekla punu nacionalnu slobodu i državnu samostalnost to je osobito značajno pitanje, kojemu je potreban razuman i stručno ravnotežan pristup. Tako je u znanstvenoj produkciji važno biti međunarodno vidljiv i kvalitetu dokazivati objavom u visokocitiranim svjetskim časopisima što podrazumijeva i objavljivanje na svjetskim (uglavnom engleskom) jezicima. No isto tako je iznimno važno objavljivati znanstvene radove i na hrvatskom jeziku kako bi se iznašli hrvatski termini za nove znanstvene pojave i procese. Jedino tako materinski jezik ostaje ,živ“ i ne tone u lokalno narječje. Takva zadaća objave u vrhunskim svjetskim časopisima na svjetskim jezicima i razvoj visoko kvalitetne znanstvene produkcije na materinskom jeziku - mora biti uzeta u obzir pri međunarodnim usporedbama, a osobito se mora uzeti u obzir kada se utvrđuju politika i kriteriji financiranja znanstvenih istraživanja. 
U tom je smislu podobna međunarodna analiza kojom se uspoređuju prirodne znanosti koje imajući uglavnom zajedničke (identične) predmete istraživanja, međusobno komuniciraju univerzalnim jezikom struke (nekoć latinskim a danas engleskim). Naime, usporedbe su dodatno objektivizirane kada su baza usporedbe „objavljivi“ radovi u prirodnim znanostima (na engleskom jeziku) umjesto ukupne znanstvene produkcije koja uključuje i međunarodno „neobjavljive“ radove (na hrvatskom jeziku u društvenim znanostima).

Takvu analizu poduzima časopis Nature objavljivanjem Nature Global Indexa (NGI), koji uspoređuje znanstvenu kvalitetu i produktivnost 100 zemalja u prirodnim znanostima. Kada se tablica NGI-ja prilagodi samo za članice EU-a tada je Hrvatska na 19. mjestu. Istodobno, prema Eurostatu, Hrvatska se s udjelom javnih bruto izdvajanja za istraživanje od 0,4\% BDP-a nalazi na 23 mjestu među članicama EU-a.

Hrvatska, dakle, na općenito niskoj razini ukupnih ulaganja, relativno efikasno ulaže u znanost, jer relativno mali broj radova, objavljen s još manje uloženih financijskih sredstava, daje rezultat nešto iznad prosjeka.

Inovacije. Mali broj inovacija u Hrvatskoj, pored ostalog, uvelike zadan strukturom odnosno ekonomskom/financijskom snagom poduzeća da ulažu u I\&R i ustrojavaju vlastite istraživačke jedinice. Ona u Hrvatskoj iznosi niskih 0,38 \% BDP-a, što nas stavlja na 24. mjesto u EU, ,ispred“ Latvije, Cipra i Rumunjske. Promjena nužno mora početi od potražnje gospodarskih subjekata za I\&R i inovativnim aktivnostima. Tehnološki zaostale i u prosjeku usitnjene hrvatske tvrtke objektivno ne mogu snositi troškove istraživanja i razvoja. Tome u prilog govori podatak kako iznos od oko 500 milijuna kuna subvencija odnosno poreznih olakšica za I\&R koristi 160-190 tvrtki. Međutim samo je 10-15 tvrtki u Hrvatskoj s vlastitim istraživačkim centrima, sposobnima sustavno emitirati inovacije. To zorno potvrđuju podaci prema kojima se šest kompanija koristi s $72 \%$ od spomenutih 500 milijuna kuna, pri čemu 2 multinacionalne kompanije koje posluju u Hrvatskoj koriste $67 \%$.

Hrvatska situacija zahtijeva među ostalim i (samo)osposobljavanje znanosti ne samo da čeka „narudžbe“ iz prakse, nego i da (dodatnim transparentnim financiranjem) „kreira“ potražnju za istraživačkim projektima koji unapređuju poslovanje i konkurentnost, okupljajući poduzetnike u centrima izvrsnosti, centrima kompetencije, znanstveno-tehnologijskim parkovima, klasterima, spin-off i spin-out pothvatima $\mathrm{i}$ drugim oblicima. Takvo neizravno -,,subvencioniranje“- i podizanje konkurentnosti nacionalnoga gospodarstva predviđeno je i Strategijom pametne specijalizacije i dopušteno EU pravilima slobodne tržišne utakmice.

Visoko obrazovanje. Hrvatsko državno osamostaljenje i stvaranje suverene demokratske države nakon 1990. stvorili su povoljno okruženje za razvoj visokoga obrazovanja. Broj studenata je više nego udvostručen: s približno 70.000 na 157.000 studenata. Uspješnost studiranja također je povećana. Broj studenata koji diplomiraju je utrostručen, od 10.000 na preko 33.000. Broj doktora znanosti i doktorskih kandidata povećan je $53 \%$. Osobito je dojmljiv obuhvat stanovništva u studentskoj dobi (19 - 23) tercijarnim obrazovanjem, koje se povećalo s $22 \%$ na gotovo $64 \%$.

Učinjeni su iskoraci u kvaliteti prema rezultatima akreditacije visokih učilišta, provedenoj po međunarodnim sustavima kvalitete $\mathrm{i}$ temeljem nalaza međunarodnih recenzenata. 
Naglasak je na uglavnom zadovoljavajućoj kvaliteti programa i nastavnika, a nezadovoljavajući su međunarodna suradnja (mobilnost) i objavljivanje u inozemnim publikacijama.

Značenje osobito visokoga obrazovanja za opstanak i prosperitet hrvatskoga i svakoga drugoga društva, čini odgovornost polazištem ocjene stanja. Tu odgovornost čine dvije komponente. Prva je individualna odgovornost prema investitorima i snositeljima rizika izbora obrazovnoga programa, struke i zapošljivosti odabrane kvalifikacije. Druga je društvena odgovornost za kvalitetu ishoda učenja i njihov utjecaj na opstojnost i društveni, gospodarski, kulturni i umjetnički boljitak vlastite države i njezine međunarodne civilizacijske stečevine.

Individualna odgovornost. Hrvatski su porezni obveznici praktično jedini investitori kojima je znanstvena zajednica visokog obrazovanja odgovorna i za koga „proizvodi“. Dakle, sadašnji i donedavni zaposlenici, koji se najmanje tri puta pojavljuje kao investitor u sustav znanosti i visokog obrazovanja;

- prvi put kao sadašnji (oko 1,400.000 ili donedavni oko 1,100.000) zaposlenici/umirovljenici odnosno proizvođači-stvaratelji koji iz svojega dohotka obvezno izdvajaju i doprinos za obrazovanje (u što je uključena i znanost),

- drugi put njih oko 2,500.000 s obiteljima kada kao zadnji potrošači u lancu plaćaju puni iznos PDV za kupljenu robu i usluge, iz čega se također proračunski ulaže i u znanost i visoko obrazovanje,

- treći put kao skrbnici koji studentu osiguravaju životne uvjete (stanovanje i druge egzistencijalne potrebe $u$ razdoblju investiranja odnosno obrazovanja) osiguravajući mu ,poček“ na povrat od ulaganja u obrazovanje.

Ukratko, oni su tvorci platežno sposobne potražnje za obrazovnim programima. Zato su načelno njihove preferencije glavni i tržišni i društveni signal za formiranje ponude a time i prvi bitan kriterij utvrđivanja upisnih kvota. Onaj tko plaća ima pravo izbora.

Ti isti porezni obveznici su (kao roditelji i njihova djeca studenti) praktično jedini ,potražitelji/potrošači““ obrazovnih programa, a time i jedini snositelji rizika zapošljivosti struke i kvalifikacije koju su stekli, i to dva puta;

- $\quad$ prvi put - obiteljski financirajući individualne egzistencijalne troškove tijekom razdoblja nezaposlenosti,

- drugi put - doprinosom za nezaposlene, financirajući opće troškove nacionalne nezaposlenosti.

Za ocjenu stanja u sustavu važno je istaknuti kako ni sveučilišta ni njihovi nastavnici, ni zavodi za zapošljavanje ni njihovi stručnjaci, ni MZO i njegovi zaposlenici, pa ni poduzetnici sa svojim trenutačno iskazanim potrebama, ne snose nikakvu materijalnu ili moralnu odgovornost za moguću nezaposlenost.

Pojednostavljeno onaj tko snosi rizik ima slobodu (informiranoga) riskiranja $u$ izboru budućega zanimanja, i zato ta sloboda izbora mora biti evidentirana i u kriterijima financiranja prema programskim ugovorima.

Društvena odgovornost. Oko 10.000 u sustavu istraživački aktivnih doktora znanosti čini oko $0,25 \%$ hrvatskoga stanovništva. Uz sve mane i vrline, to je „elita“ na 
kojoj počiva velika stručna odgovornost dostizanja životnih uvjeta razvijenoga dijela Europe u razumnom roku radnoga vijeka sljedeće generacije. Među ostalim, odgovornost proizlazi i iz triju razloga koji se ukupno mogu procijeniti na oko 55 milijarda kuna:

- 20 godina školovanja - 5 milijarda kuna. Prosječno 20 godina školovanja doktora znanosti društvena je investicija od približno 500.000 odnosno ukupno oko 5 milijarda kuna.

- 20 godina radnog iskustva - 36 milijarda kuna. Prosječno 20 godina radnoga iskustva doktora znanosti s prosječnim (proračunskim) mjesečnim bruto primanjima od 15.000 kuna društvena je investicija od približno 36 milijarda kuna.

- $728000 \mathrm{~m}^{2}$ nastavno opremljenoga prostora - 13,5 milijarda kuna. Evidentiranih $728000 \mathrm{~m}^{2}$ nastavno opremljenog prostora (po cijeni od prosječno 18,5 tisuća $\mathrm{kn} / \mathrm{m}^{2}$ ) društvena je investicija od približno 13,5 milijarda kuna.

Potrebu kritičke analize krupnih nedostataka i pozitivnih rezultata visokoga obrazovanja valja staviti u kontekst izrazito nepovoljnih trendova u financiranju, koji osobito u razdoblju krize 2009. - 2014. bitno utječu kako na kvalitetu tako i na položaj nacionalnoga sustava u europskome okruženju jer je:

- državni proračun povećan $(+8,5 \%)$,

- $\quad$ proračun MZO za Visoko obrazovanje i znanost u njemu je smanjen (- 4,5 \%),

- broj studenata na fakultetima je povećan $(+11,6 \%)$.

Europska unija strategijski cilj u visokoj naobrazbi definira kao udjel od 40\% tercijarno obrazovanih u strukturi radne snage u dobi od 25 - 65 godina, a negdje i više. Štoviše, rast udjela visokoobrazovanoga stanovništva vidi se kao bitan element dugoročnoga uspješnoga i održivoga rasta. Trenutačno je u razvijenome dijelu EU-a udjel visokoobrazovanih u strukturi radne snage oko $30 \%$, a u Hrvatskoj ispod $20 \%$.

Konkretno stanje potražnje za tercijarno obrazovanim kvalifikacijama na hrvatskome tržištu rada, pokazuje relativnu stabilnost i parcijalnu ravnotežu ponude i potražnje. Raspoloživi podaci dobrim dijelom osporavaju tvrdnje o nezadovoljavajućoj kvalifikacijskoj strukturi tercijarno obrazovanih, među kojima dominiraju društvene znanosti, osobito ekonomske i pravne, posredno odgovarajući na dva pitanja.

Pojednostavljeno, prvo je pitanje proizvodimo li (zbog prevelikoga broja studenata u društvenom i humanističkom području), stručnjake za „burzu“ umjesto tržišta rada? Odgovor je: Ne, ne proizvodimo. Naime od 2010. - 2017. hrvatski visoko-obrazovni sustav ,proizvodi““ oko 32.000 diplomiranih studenata. Taj se broj može usporediti s brojem nezaposlenih tercijarno obrazovanih bez radnoga iskustva, prijavljenih na zavodu za zapošljavanje. On broj varira s poslovnim ciklusom. Od 6.908 u 2010., „Zagrijavanjem“ krize 2014. godine taj je broj porastao na 10.755. No, gospodarskim oporavkom u 2017. taj je broj smanjen na 5.038.

Drugo je pitanje, proizvodi li visoko obrazovanje nezaposlenost umjesto rasta? Odgovor i na ovo pitanje je: Ne, ne proizvodi. U razdoblju krize od 2010. - 2014. povećao 
se udjel tercijarno obrazovanih nezaposlenih u ukupnoj nezaposlenosti s 2,9 na 3,2\%. No umjerenim oporavkom taj se odnos u 2017. smanjio na 2,6\%.

Statistički dokumentiran odgovor na oba pitanja upućuje na tzv. cikličku nezaposlenost tercijarno obrazovanih prouzročenu stanjem poslovnog ciklusa. Istodobno, odgovor ne upućuje na tzv. strukturnu nezaposlenost tercijarno obrazovanih koja bi bila prouzročena neodgovarajućom strukturom ponude tercijarno obrazovanih struka $\mathrm{i}$ kvalifikacija.

Prema tri međunarodna izvora, financiranje visokog obrazovanja i znanosti primaran je problem hrvatskog sustava. Prvi puta $\mathrm{u}$ prethodnoj analizi ulaganja $\mathrm{u}$ znanstvena istraživanja i u I\&R Europske komisije odnosno Eurostata. Drugi puta ga identificira sofisticirana analiza Universitas 21 rankinga. Po treći put ga spominje analiza UNESCO-a.

Time razvidnim postaje ne samo zaostajanje, nego i divergencija u odnosu na EU trendove kada se radi o financiranju obrazovanja, osobito visokog, koji s oskudnim ulaganjima u pravilu daje rezultate nešto iznad prosjeka. Tako uspostavljeno dugotrajno funkcioniranje temeljem niske razine financiranja ima gotovo razoran učinak na učinkovitost sustava. Kritička analiza stanja upućuje na zaključak kako istraživački i obrazovni trendovi pokazuju ozbiljno zaostajanje Hrvatske s nespornim dugoročnim negativnim učincima na modernizaciju i restrukturiranje hrvatskoga gospodarstva te na inovativnost i apsorpcijski kapacitet u primjeni novih tehnologija. Stoga su definirani ciljevi koje se zakonom namjerava postići. U ishodištu su istraživači-nastavnici kod kojih ciljevi poboljšanja kvalitete pretpostavljaju sljedeće: u prosjeku jedan znanstveni rad godišnje u visoko rangiranom međunarodnom časopisu, inozemno usavršavanje, praksu i suradnju s hrvatskim gospodarskim i društvenim subjektima, pedagoško usavršavanje i osposobljavanje za digitalizirane metode poučavanja. U tom su smislu razrađeni kriteriji znanstvenoga i nastavnoga napredovanja. Bitan je cilj unapređenje kvalitete i internacionalizacije nastavnih programa i institucija, što pretpostavlja povećanu međunarodnu konkurentnost uvođenjem višejezične nastave na hrvatskom i svjetskim jezicima, važnima za pojedine struke, povećanu odlaznu mobilnost nastavnika i studenata, osobito u STEM području, i hvatanju istraživačko-tehnološkog priključka sa suvremenim razvitkom, povećanu dolaznu mobilnost, osobito u - društvenohumanističkom (DH) području, osiguravajući međunarodnu vidljivost hrvatskih nacionalnih društvenih, povijesnih, arheoloških, kulturnih, umjetničkih i drugih specifičnih doprinosa međunarodnoj zajednici, uvođenje obveze minimalno jednomjesečne prakse studenata tijekom svake godine preddiplomskoga/diplomskoga studija, omogućavanje protočnosti nastavnika između razina tercijarnoga obrazovanja, koncentraciju nastavnih obveza nastavnika voditelja istraživačkih projekata na doktorskim studijima, uvođenje mentorske nastave. Institucionalna rješenja kojima se potiču znanstvena izvrsnost, međunarodna mobilnost i internacionalizacija, suradnja $\mathrm{s}$ gospodarstvom i inovativna aktivnost obuhvaćaju sveučilišne znanstveno-inovacijske institute, centre za međunarodnu suradnju i mobilnost, centre za cjeloživotno obrazovanje i transfer tehnologije.

Reformska rješenja znanstvenoj djelatnosti i visokom obrazovanju institucionalno pozicionira sveučilišnu autonomiju kao (samo)odgovornost za slobodu i 
kvalitetu visoko obrazovnoga procesa $\mathrm{i}$ istraživanja. Polazeći od činjenice da nitko nije bolje kvalificiran, u znanstveno-stručnom pogledu, ocijeniti kvalitetu nastavnika, programa i institucija od akademske zajednice, nužno je od nje tražiti dragovoljno podvrgavanje strogim moralnim načelima i razrađenom etičkom kodeksu.

Provođenje ovako formuliranih rješenja kojima se, krupnim reformama, institucionaliziraju duboke promjene u sustavu i realiziraju ciljevi i mjere Strategije obrazovanja, znanosti i tehnologije, zahtijevat će dodatna sredstva. U skladu s preporukama Europske komisije, bilo bi potrebno postupno povećavati nacionalna javna izdvajanja za najmanje 10\% godišnje u sljedećih 7-10 godina, uz učinkovitije korištenje raspoloživih sredstava kohezijskih fondova.

\section{LITERATURA:}

1. AZVO (2015) Sinteza reakreditacije provedene $u$ akademskoj godini 2014./2015.

2. AZVO (2019) Ukupan broj studenata po tipu studija i tipu visokih učilišta, https://www.azvo.hr/hr/visoko-obrazovanje/statistike/44-statistike/690-ukupanbroj-studenata-po-tipu-visokih-uilita-za-0910-i-1011

3. Benda, J. (1997) Izdaja intelektualca, Politička kultura, Zagreb

4. Bok, D. (2013) Higher Education in America, Princeton University Press, USA

5. Doolan. K.,Dolenec, D., Domazet, M. (2012.) Hrvatski sustav visokog obrazovanja u europskom kontekstu, Institut za razvoj obrazovanja, Zagreb

6. Družić, I. (2014) Obrazovanje i razvojni ciklusi u Družić, G., Družić, I. Razvojni potencijali hrvatskog gospodarstva HAZU Zagreb, str. 333-372.

7. Družić I. (2018) Komparativni učinak proračunske troškovne umjesto investicijske paradigme na razvojnu funkciju znanosti $i$ visokog obrazovanja $\mathrm{u}$ Družić, G.., Družić, I. Modeli razvoja hrvatskog gospodarstva. HAZU,. str.215246.

8. Družić, I. (2019) Sustav znanosti i visokog obrazovanja u Barbić, J. ur. Istine i zablude o reformi visokog obrazovanja, HAZU 2019., str. 21-70

9. DZS (2009) https://www.dzs.hr/Hrv/publication/2009/8-1-7_1h2009.htm

10. DZS (2016), Visoko obrazovanje u 2016., Statističko izvješće 1599

11. European Commission (2015), Preliminarni izračun DG RTD/JRC, Brussels

12. European Commission (2017a) $L A B-F A B$-APP Investing in the European future we want, B-1049, Brussels

13. European Commission (2017b), Towards a European Education Area, Weekly Meetings, 14 November, https://ec.europa.eu/

14. European Commission (2018a) Country Report Croatia 2018, Brussels, str. 43.

15. European Commission (2018b) Science, Research and Innovation Performance of the EU 2018

16. European Commision (2018c) The Higher Education European Area in 2018. - Bologna process Implementation Report, str. 255,256

17. Europska unija (2013) Horizon/Obzor 2020, MZOS RH 
18. Eurostat (2015) News Release 209/2015, Brussels

19. Eurostat (2019a), http://appsso.eurostat.ec.europa.eu/nui/show.do?dataset=rd_e_gerdtot\&lang=e $\mathrm{n}$

20. Eurostat (2019b), https://ec.europa.eu/eurostat/web/science-technologyinnovation/overview

21. Eurostat (2019c), Prijave patenata Europskom uredu za patente (EPO), http://appsso.eurostat.ec.europa.eu/nui/show.do?dataset=pat_ep_ntot\&lang=en

22. Frey, C.B., Osborne, M.A. (2013) The Future of Employment: How Suspectible are Jobs to Computerisation, https://www.oxfordmartin.ox.ac.uk/publications/view/1314

23. Institut za statistiku UNESCO-a (2012) - http://data.uis.unesco.org/

24. MZO (2018) Povjerenstvo za izradu Nacrta prijedloga Zakona o znanstvenoj djelatnosti i visokom obrazovanju „Nacrt prijedloga Zakona o znanstvenoj djelatnosti“" od 23. 10. 2018. - Ocjena stanja i osnovna pitanja koja treba urediti zakonom te posljedice njegova donošenja (Napomena: podloga za diskusiju ne reflektira u cijelosti mišljenje povjerenstva niti je službeni stav ministarstva)

25. MZOS (2014) Plan razvoja istraživačke i inovacijske infrastrukture u Republici Hrvatskoj, str 41-48, Dodatak 3. - Popis kapitalne opreme nabavne vrijednosti veće o $1,000.000,00 \mathrm{kn}$

26. Nature Index (2017) A guide to the Nature Indeks, Nature volume 550, p. 192

27. Nature Index Global (2014) Nature Index Tables, MacMillan Group

28. NVZVOTR (2016/2017), Izvješća o radu NVZVOTR-a za 2016. i 2017.

29. Porezna uprava (2014), Pregled poreznih obveznika koji su u prijavi poreza na dobit (PD obrascu) za 2011. i 2012. godinu iskazali državnu potporu za istraživačko-razvojne projekte (rb. 34.2. PD obrasca)

30. Staničić, F. (2019), Obrazloženje Nacrta prijedloga Zakona o znanstvenoj djelatnosti i visokom obrazovanju, Senat Sveučilišta u Zagrebu, 22.1.2019.

31. Strategija obrazovanja, znanosti i tehnologije (2014) NN 124/14

32. Universitas 21 (2017) Ranking of National Higher Education Systems-Full Report, Melbourne Institute for Applied Social and Economc Research,

33. https://universitas21.com/sites/default/files/201803/2017\%20full\%20report.pdf

34. Ustav Republike Hrvatske (2010) Narodne novine, broj 85/2010. - pročišćeni tekst i 5/2014. - Odluka Ustavnoga suda Republike Hrvatske.

35. Vlada RH (2016) Odluka o donošenju Strategije pametne specijalizacije Republike Hrvatske za razdoblje od 2016 do 2020 godine i Akcijski plan za provedbu Strategije pametne specijalizacije Republike Hrvatske za razdoblje od 2016 do 2017 godine,

36. https://www.ciraz.hr/wpcontent/uploads/2016/10/Strategija_pametne_specijalizacije_RH_2016_2020.p df

37. Wikipedia (2019) List of countries by GDP (nominal), https://wikipedia.org 
38. World Bank (2008) The Growth Report, Commision on Growth and Development, Washington, SAD

39. World Bank (2013) Overview of the Research and Innovation Sector in the Western Balkans, World Bank Technical Assistance Project (P123211), str 9

40. World Economic Forum (2016) The Future of Jobs, https://www.weforum.org

41. World Economic Forum (2019), Global Competitive Indeks 2017/2018, https://weforum.org

42. Zakon o znanstvenoj djelatnosti i visokom obrazovanju-pročišćeni tekst (2014) NN 123/03., 105/04., 174/04., 2/07. - Odluka Ustavnoga suda Republike Hrvatske, 46/07., 45/09., 63/11., 94/13., 139/13., 101/14. - Odluka Ustavnoga suda Republike Hrvatske, 60/15. - Odluka Ustavnoga suda Republike Hrvatske, i 131/17. - Uredba Vlade Republike Hrvatske

43. Zakon o akademskim i stručnim nazivima i akademskom stupnju (2012) $N N$ 107/07, 118/12

44. Zakon o hrvatskom kvalifikacijskom okviru (2018) NN 22/13, NN 41/16 Odluka Ustavnoga suda, 64/18

45. Zakon o osiguranju kvalitete u znanosti i visokom obrazovanju (2009) NN 45/09

46. Zakon o Hrvatskoj zakladi za znanost (2012) $N N$ 117/01, 92/10, 78/12

47. Zakon o općem upravnom postupku (2009) NN 47/09 


\title{
INSTITUTIONALIZATION OF THE REFORM OF THE CROATIAN SYSTEM OF SCIENCE AND HIGHER EDUCATION ${ }^{29}$
}

\author{
Ivo Družić
}

\begin{abstract}
Summary
The undoubted growing influence of science and higher education calls for an innovative institutional conception and the structural reform of the system based on it. The starting point of such an approach to legal regulation is the adaptation of the Croatian system of science and higher education to the new, globally recognized, leading role of education and scientific research in the overall social, economic, cultural and artistic as well as personal development. This role is evident in new technological and organizational patterns where human resources become (infrastructural) a prerequisite for innovative and effective progress. The new role, among other things, carries with it a special responsibility of science and higher education in addressing the accompanying social challenges. Philosophical, aesthetic, cultural and ethical aspects of high technologies and new realities require institutional solutions that encourage the accelerated development of both the system and quality of higher education and the intensification and raising of the international relevance of scientific research and innovation activities. This is a fundamental precondition for capturing the European development step and incorporating Croatian national identity into the evolution of the European civilization circle. As the quality of researchers and teachers, programs and institutions is the key to the reform transformation, the quality assurance system must be incorporated as an integral part of the appropriate legal solution.

Key words: system of science and higher education, reform of the system of science and higher education, institutional framework, the quality assurance system, Republic of Croatia.
\end{abstract}

\footnotetext{
${ }^{29}$ The study presented in this text was part of the scientific and professional background in conceiving a comprehensive reform of the science and higher education system and its institutionalization in the draft of the new Law on Scientific Activity and Higher Education proposed by the University of Zagreb in March 2019.
} 